\title{
Y
}

\section{Romada Aynî Haklar}

\author{
(Jus Rerum)
}

Asistan. Dr. Sakir Berki

Aynî hak bir şahsın bir șey üzerinde vasıtasız ve her kese karșı dermeyan edilebilecek olan yetkisidir. Roma hukukunda aynî hakkın hangi șeyler üzerinde tesis edilebileceğini anlayabilmek için, bu bahsin ilk faslını șeylerIn tasnifine ve, Roma hukukunda mamelek mefhumu daha ziyade şeylerle ilgili bulunduğundan, Patrimoniuma tahsis etmeği doğru bulduk.

\section{Birinci Fasıl}

Seylerin tasnifi ve Mamelek (Patrimonium).

\section{I - Seylerin tasnifi.}

Justinianus hukukuna da geçmiş olan ve Gaius tarafindan yapılmış bulunan (1) tasnifi takip edeceğiz.

1. Res eXtra Patrimonium (2) (Mameleke dahil olamayan seyler).

2. Res in Patrimonium (Mameleke girebilen eşya)

1. Res extra patrimonium.

(1) - Impartaorluk devrine kadar Roma hukukunda res in corporalislerin henüz doğmamıs olduğu görülüyor: R. Monier, Manuel, 1945, +1. p: 341, n: 1; Aksi manada: Ed. Cuq, Manuel, 1928, p: 237 .

(2) - R. Monier gibi bazı müell.fler (Manuel, 1945. †. 1. p: 343) yukarıdaki tabirler yerine res extra commercio ve res in commercio tabiplerinin kullanilmasını daha muva. fik bulmakta iseler de, bunun daha doğru alamavacağı kanaati de güdülebilir. Filhaki$k a$, eğer bir sev res extra commercio kategorisine dahil ise mameleke dahil olmayan bir sey, yani res extra patrimonium dur. Bilâkis, Res extra patrimonium tâbiri daha samil ve binnetice daha elverislidir, zira, eșva mutiâka commercium «dar manada hukukî muamele ile mame!eke dahil olmaz; Occupatio, spesificatio, ilh. bunu tevide kâtidir. 
Gerek maddî, gerek hukukî imkânsızlık dolayısı ile ferdî mameleke dahil olmayan seylerdir. Bu itibarladır ki bu seylere Res nullius da denir.

Res extrapatrimonium iki kategoriye ayrilır:

A - Res nullis divini juris.

Dini gayelere tahsis edilmiş olmaları sebebi ile mameleke giremeyen eşyadır .

Așağıda zikri geçen eşya res nullius divini juris kategorisine dahildir:

a) Res sacrae. (3)

Pontifler tarafından büyük ilâhlara tahsis edilmiş olan şeylerdir: Ibadet yerleri, ibadete yarayan eşya bu nevidendir. (4)

b) Res religiosae. (5)

Mezarlar (sepulcra) ve etrafinı çeviren arsacıklar bu kategoriye giren. dinî eşyadandır. Bu eșya üzerinde bazı şahıslara tanınmış olan nezaret ve ziyaret hakkı (jus sepulcri) ölünün akrabalarına aittir.

c) Res sanctae.

Tanrıların himayesine terk edilmiş addolunan șehir duvarları (surlar) erazi sinırları res sanctae dendirler.

B - Res Mullius humani juris. (6)

Justinianus hukuku bu kategoriye dahil eşyayı üçe ayırryor:

a) Res communes.

Mahiyetleri, tabiî yapılıșları itibariyle mameleke dahil olmayan șeylerdir: Akar sular, hava, deniz gibi.

b) Res publicae.

Roma devletinin mamelekine hâs, Roma halkına ait eşyadır. Limanlar, yollar, parklar gibi.

c) Res universitatis.

Müstakil mameleklere dahil bulunmakla beraber halkın faydalanmasina amâde olan şeylerdir. Belediyelere ait hamamlar, tiyatrolar gibi. (7)

(3) - G. Le Bras, Studi-Riccobono, III. p: 23 et s.

(4) - Roma halkının reyi ile dinî mahivet almıs olan bir şey yine onun reyi ile bu vasfı kaybedebilir.

(5) -- Ed. Cuq, Rev. hist. de droit, 1930, p: 383 et s; Ed. Cuq, Le rescrit d'Auguste sor les violations de sépultures (Rev. hist. de droit, 1932, p: 109 et s.)

(6) - Karadgé, Les choses publiques en droit romain, Thèse, Paris, 1928.

(7) - Bu eşvadan faydalanmasına mani olunan her Romalı hakarete uŏramış sa. vilir ve actio injuriarum dan faydalanır: Giffard, Précis, 1934. †. I. p: 318. 


\section{Res in Patrimonium.}

Bir șey ya doğrudan doğruya mameleke salihtir, veya evvelâ ferdi mameleke salih değilken bilâhara hukuki bir muemele ile salih olur. Amme mallarının, meselâ amme kölesinin fertlere satılması halinde hal böyledir.

Biz bu paragrafda mahiyetleri itibariyle, başka bir deyimle, doğrudan doğruya ferdî mameleke girmeğe amâde bulunan eşyanın tasnifinden bahsedeceğiz.

Romada Res in patrimonium tasnifi res exstra patrimonium tasnifinden daha ehemmiyetlidir; çünki, borçlar hukuku ve ticaret hayatının temelini bu eşya teskil eder.

Res in patrimonium iki kısma ayrilır:

A - Res mancipi.

B - Res nec mancipi. (8)

Bu tasnif Imparatorluk devrine kadar Romada eşyanın en esaslı tasnifi olarak devam etti.

4) Res mancipi gurubu Roma ziraaat hayatına yarayan bütün menkul ve gayri menkul eşyayı ihtiva eder: Italya erazisi, köleler, binalar, çift hayvanları (9) ve aracları ilh.. gibi ziraî ve iktisadî hayatın zarurî elemanlarını teşkil eden eşya reș mancipi dir.

3) Res nec mancipi grubuna mancipi olmayan bütün eşya dahildir: Eyaletlerdeki erazi, koyun ve keçi, para nec mancipi esyadandır.

Res nec mancipi ler ziraat hayałı ile yakından ilgili olmadığından Romalılarca daha az kıymetli şeylerdir.

Esyanın res mancipi ve res nec mancipi olarak ikiye taksiminin hukukî ehemmiyeti mülkiyetin intikali usullerinde göze çarpar (10): Res nec mancipi Jer Traditio, res mancipi ler Mancipatio veya in jure cessio ile devredilirter.

Romalılar Res in patrimoniumu hukukî mukadderatı bakımından da tâli taksime uğratmışlardır:

(8) -. P. Koschaker, Z. der. Sav. Stift, 1938, p. 259 et s; Cornil, Rev. hist. de droif 1937 r: 555 ef :, A. Giffard, Mancipium (Rev. de philologie, 1937. p: 396 et s:

(9) - Deve ve fil res mancipi değildir: R. Monier, Rev, hist. de droit, 1930, p: 119 et s.

(10) - F. de Visscher, Rev, des études latines, 1936, p: 130 et s. Ancak res mancipiler .mancipatio ile devredilebilirler: Gaius, 11, 18 - 19; Resit kadinlar res nec mancipi leri vasinin rızasına lüzum olmadan, res mancipi leri ise mutlâka müsadesi ile devredabilirLer: Gaius, 11, 80. 


\section{C - Genera ve species eşya.}

Hukukî muamelede taraflar verilecek şeyi tasrih etmemişlerse sey genera, yani gayri muayyendir, etmișlerse muayyen (species) dir. Bu taksimin hukukî ehemmiyeti şudur: Res genera nın borçlusu alternatif bir borcun borçlusu gibidir. Şey kusur haricinde zayi olsa bile aynı cinsten diğeri verilecektir. Halbuki, res species de kusur haricinde ziya borcun sukut sebebidir.

D - Res qui numero, qui pondere, mensurave.

Sayılabilen, tartılabilen ölçülebilen eşya.

Bunlar hukukî muamelâtta ayrı ayrı belirtilmiş olmalarına lüzum ve hattâ bazan da imkân olmayan esyadır: para, buğday gibi.

Bu tasnifin hukukî ehemmiyeti ancak bu eşyanın lare aktine mevzu teşkil edebilecekleri ile izah olunabilir.

E - Mütecanis (basit) ve mürekkep eşya. (11)

Klâsik devir hukukçuları mameleke dahil olan ve müstakil varlık gösteren şeyleri üçe ayırırlar: gibi.

a) Tamamiyle müstakil bir varlık gösteren șeyler: bir direk, bir köle

b) Maddî bakımdan tamamiyle müstakil varlıklardan, eşyadan meydana gelen şeyler: sürü gibi.

Bu taksimin hukukî ehemmiyetini șu suretle izah etmek mümkündür:

$1_{0}$ ) Basit șeyler hukukî muamelenin bütün neticelerine tâbidirler: bir köleyi satın alan onun büłününe, her kısmına sahip olur.

$\left.2^{\circ}\right)$ Mürekkep şeylerden ikinci kategoriye girenler hukukî muamelenin bütün neticeleri ile ilgili değildirler: bir evi usucapio ile iktisap eden şahıs evin mülkiyetine sahip olur ise de, evin malzemesi bașkasına ait ise malzemeye sarî değildir. (12)

$\left.3^{\circ}\right)$ Müstakil ve mütecanis șeylerden müteșekkil mürekkep șeyin bütününün iktisabı onu teşkil eden bir ve hattâ daha ziyade müstakil şeyin iktisabı ile mümkün değildir: Bir sürüye sahip olabilmek için buna dahil bir veya dört koyunun usucapio su kâfi değidir. Fakat, bir sürüye istihkak davası onu teşkil eden her müstakil şey (koyun) hakkında ayrı ayrı rei vindicatio ya müracaatı icap ettirmez.

111) - P. Bonfante, Corso, 11. 1926, p: 100 et s; G. Micolier, Pécule et capacité patrimoniale; 1932, $\mathrm{p}: 78$ et $\mathrm{s}$.

(12) - Bossovki, Studi Riccobono, 111; p: 257 et s: 
F - Müłemmim cüzü, teferruat ve semere.

a) Müremmim cüzü.

Aslî veya mürekkep şeyden filen ve hukuken ayrilmasına imkân olmayan, ayrıldığı taktirde bunarın cevheri aslissinde iktisadî ve kıymet bakımından esaslı değişikliğe meydan veren șeylere mütemmim cüzü, tamamlayıcı parçaları denir. Bir evin çatısı; hibeye dahil şeylerden briinin ayrılması hibe mevzuunun cevherinde maddî ve hukukî noksanlıklara mahal vereceğinden, çatı ve hibe mevzuundan ayrılan şey müłemmim cüzüdür. (13)

Su halde mütemmim cüzülerin hukukî mukadderatı asıl şeyin tâbi olduğu hukukî muamele ile tayyün eder: saatin kulpu, saat satılırken satılmıs sayilır.

b) Teferruat. (instrumento). (14)

Aslî şeyin kullanılmasını kolaylaştıran ve ondan ayrıdığı zaman cevheri aslísine, özüne tesir etmeyen sahip şahsın iradesine tâbi bulunan șeydir.

Romada erazinin ișlenmesine yarayan köle ve hayvanlar ve ziraał alâtı erazinin teferruatındandır. Arazi sahibi isterse erazi ile birlikte bu teferruatı satabilir, dilerse yalnız eraziyi (aslî șey) devreder.

c) Semere (Fructus).

Aslî şeyin kıymeti eksilmeksizin, düşmeksizin yarattığı maddî veya hukukî şeylerdir. Ağacın meyvesi, paranın faizi gibi.

Roma hukukçuları semere ile hasılatı birbirine yaklaștırmak suretiyle birlikte mütalâa ederler. Faiz ve kira bedeli de semeredir. (16)

Şu halde, semere iki çeşittir:

$\left.1^{\circ}\right)$ Tabiî semere.

Aslî șeyin fitretinde; cevherinde bulunan semerelerdir: koynunun sütü, yünü gibi. (17) Kölenin çocuğunu (Patrus ancillae) semere sayıp saymamak münakaşalı idi: Müspet cevabı takip eden $Q$ Mucuis Scaevila nın fikrini ana ráhmindeki partus ancillae için doğru bulmak lâzımdır. Aksi takdirde, yani

(13) - Isaret edelim ki ibe mevzuundan avrísir her sey mütemmim cüzü savilamaz, sayılabilmesi için umumî efkârın ayrılan o seyin mutlâka mevzua dahil bulunması zaru. retine hükmetmesi gerekir.

(14) - Steinwenter, Fructus cum instrumenio, 1942, p: 110.

(16) - Pomponius (D. 50. 16, fr. 121) faizi semereden saymaz.

(17) - Havvan vavrusu doğmadan evvel semere, doğduktan sonra Fructus separati den ziyade asli şeydir. mamafih, yavruyu besi bakımindan anasından ayırmakta mah. zur varsa, fructus separati saymak lâzımdir. 
çocuk doğduğu andan itibaren, menfi mütalâada bulunan Junius Brutus $u$ takip etmek doğru olur; zira, Roma hukuku imtidadınca filen sahsiyet ahline geçmiş, yani doğmuş olan köleler ana ve babaları gibi hukukun himayesine nail olmus bulunmak suretiyle tam manası ile res mancipi olmaktan kurtulmuş bir varıkdan, insandan ibarettirler. (18)

Aslî şeyle olan ilgilerine göre tabiî semereleri üçe ayırmak mümkündür:

a) Frucíus pendentes.

Aslî șeyle irtibatı kesilmemiș olan semerlerdir ki, tam manası ile semereye tekabul etmezler.

b) Fructus separati.

Aslî şeyden arızî olarak ayrılan meyvelerdir. Rüzgar ile dökülmüş elmalar buna misaldir.

c) Fructus recepti.

Irade ile toplanmıs olan semerelerdir. Bunlar da ya exi trantes, yani halen mevcul, veya consumpti, yani yenilmek veya satılmak suretiyle elden çıkarılmıs, istihlâk edilmiş olan semereler olarak ikiye ayrilır.

Semerelerin bu taksiminin bilhassa iade bakımından ehemmiyeti vardır: hüsnü niyetli zilyed fructus consumpti lerden prensip itibariyle mesul değildir.

$2^{\circ}$ ) Medeni (hukukî) semereler.

Evelce de beyan olunduğu üzere Roma hasllat ile medeni semereleri bir tutmuștur. Medeni semere ile kanunî semere arasındaki en bariz fark bu berikilerin aslî șeyin bir parçası olmadığıdır. lcar bedeli ve faizde hal böyledir.

G - Menkul ve gayri menkul eşya. (19)

Imparatorluk devrine kadar seylerin en ehemmiyetli tasnifi res mancipi ve res nec mancipi olarak devam ettiğinden, menkul ve gayri menkul tasnifine ancak bu devirden itibaren raslanır. Mamafih, bu tasnifin Romada ehemmiyeti yok denilebilecek kadar sönüktür. (20) Fakat, her halde, cüz'i ehemmiyeti de mülkiyetin intikalinde mevzu bahis değildit.

II - Patrimonium (Mamelek).

1. Umumî bilgi.

Mamelek bir şahsın para ile ölçülebilen hak ve mükellefiyetlerinin hepsini ihtiva eden mücerret hukukî bir zarftan ibarettir. \$u halde mamelek anla-

(18) - Partus anciliae için, bakiniz: Basanof, Partus ancillae, Thèse, Paris, 1929.

1191 - B. Klüber, Res mobiles und res immobiles (St. Bonfante. 11, p, 346 et s.)

(20) - R. Monier, Manual, t. 11, 1944, 353, no. 254, n: 3, 4. 
mına aynî haklar ve borçlar ve nihayet miras hukukunun aktif ve passif hükümleri girer. Sırf şahsa bağlı özel hukuk ve kamu hukukunun hak ve mükellefiyetleri mameleke dahil değildir: aile reisliği, delvet şefliği, oy hakkı ith mamelek mefhumu haricindedir.

Romalılar mamelek mefhumunu ilk zamanlarda tanımayorlardı, ve son- raları da, hattâ justinianus hukukunda bile, mamelek mefhumunu modern manası ile kabul etmediler.

ilk zamanlarda patrimonium paterin emrinde bulunan malları ifade eder, alacak ve borçları ihtiva etmez. Bu, adrogatio ile evlâtlığa alınan șahsın bütün mallarının evlât edinen patere intikal etmesine mukabil, borçlarının sönmesi hadisesi ile teyid edilir. Pretör hukukunun bu hususda koymuș olduğu islâh edici kaide (21) Romada mamelek mefhumuna doğru bir ilerleyiş olarak kabul de edilemez; çünkü, borçlardan mesuliyet bizatihi mamelek mefhumundan doğan bir neticedir.

Esasen pretörün yaptığı yenilik alacak!ılar lehine alınmış münferid tedbirlerden ibaretti.

Bazı müellifler (22) Roma hukukunda mamelek mefhumunun bilirtilmekte olușuna mirascının müteveffanın mallarına sahip olmakla beraber ocağının ibadetini devam mükellefiyetine de tâbi bulunduğunu zikretmektedirler. Fakat sacra borcunu mamelekle ilgili görmek doğru değildir, zira mameleke dahil borçlar para ile taktir edilebilecek borçlardır.

Romada res corporales ile res in corporalesi de ihtiva eden patrimonium mefhumunun menșeini mirascının mütevffanın alacaklılarına karşı mesul tutulduğu tarihe kadar uzatmak lâzımdır. Su halde, patrimonum tabiri Romada her şeyden evvel maddî eşyayı ifade eder. (23)

Roma hukukunda modern mameleki ifade edebilecek olan tek tabirin "Universitas juris» olduğunda ekseriyetle karar, kılınmıştır. (24) Bu tabir ile Romada, bilhassa, miras bahsinde, mamelek mefhumu belirdi.

(21) - Pretör hukukunun bu husustaki faaliveti için Capitis deminitio ve Adgoratio onun neticeleri bahisleririe bakınız.

(22) - R. Monier, Manuel, 1945. t. 1; p: 347, No: 249.

(23) - Ed. Cua, Manuel, 1928, p: 916 . Aksi manada: Giffard, Précis, 1934. t. 1. p: 320

(24) - R. Monier, Manuel, 1945, t. I. p: 348: Hermogeni anus (D. 50; 16: fr: 222) torafından kullanilar. Pecunia tâbiri de hukukî manasiyle mameleki ifade etmeyio ancak patrimonium un aktif kısmının bütün sumılünü göstermeğe yarar. 
Peculium'uda Romada mamelekin nikişafina dair beliren bir müessese olarak kabul etmek doğrudur. Fakat, bazı müeliiflerin hilâfına olarak, köleye ait peculiuma quasi patrimonium mahiyeti izafe efmek bizce doğru değidir; çünkü, hukukî manasında mamelek mefhumunun aktif kısmı daima zenginleşmeğe amâdedir. Halbuki köle ve hattâ alieni jurisler prensip itibariyle kendileri için ehil değildirler. Bundan başska, hukukî manasiyle patrimonium ona dahil kıymetlerin hak sahibi tarafından devrini mümkün kılan bir mefhumdur. Alieni jurisler P. Q. castrense lerinde ölüme bağh tasarruflarda buunmazlardı.

Modren mamelek anlamı şahsiyetle ilgili olduğundan ve modern hukukda herkes șahsiyetten müvasatten faydalandiğındian mamelekin aktif ve passif kapısı daima açıkır: bir şahıs aktif kısmı istediai kadar zenginleștirmekde ve passifi azaltmakta serbestir. Romada köle bizzat mameleke dahil bulunduğundan onun pekkülüne quasi patrimonium adı vermek hayli güçtür.

2. Mamelek bakımından Roma hukuku -ile modern hukuk arasinda ki fark.

A - Prensipte fark.

Modern hukukda herkes şahsiyete sahiptir, binnetice, bir mameleke sahiptir. Romada, kölelik Romanın inkırazına kadar devam ettiğinden, herhes mameleke sahip değildir.

B - Mamelekin faydalanan şahıslar bakımından tark.

Zamanımızda iktisap ve ittizam ehliyetine, yani hem aktif hem passif ehliyete ve hattâ yalnız ikincisine sahip olan herkes mameleke tahditsiz olarak sahiptir. Romada, rüșde erişmiş olsa bile, alieni juris lerin mamelek hüriyetleri kısıntıya uğramıştır. Roma, tam mamelek ehliyetini ancak sui juris lere tanır.

Ikinci Fasıl.

\section{Mülkiyet (Dominium) (25)}

1 - Mülkiyetin menşei ve tarihçesi.

1. Mülkiyetin menşei.

Bazı hukukçular (26) Romada mülkiyetin ilk defa res mancipi ler üzerin-

(25) - P. Huvelin, Cours, I. 1927, p: 425 et s; R. Besnier, Observations sur les vicciti. tudes de la notion romaine de la propriété: (Annales d'hist écon et sociale. 1937, $p$ : 320 et $s$.

(26) - Ed. Cua, Mnavel, 1928, p: 243, 292; Girard, Manuel, 1929. p: 272. 
de mevzu bahis olduğunu, bazıları da (27) mülkiyetin en eski devirlerde resnec mancipi ler hakkında da kabul edilmiş bulunduğunu iddia etmektedirler.

Milâttan evvel ikinci asırda meriyete giren lex aquilia nın her çeșit ve hattâ res nec mancipi sayılan keçi ve koyun sahiplerini de çift hayvanları sahipleri gibi himaye etmiş olması bu asırlarda res nec mancipi lerin de mülkiyet mefhumuna dahil bulunduğunu ispata bir veskia sayılabilir. Mamafih, birinci kategoriye dahil hukukçulara uyarak, Romada ilk defa hukukî manasiyle mülkiyet anlamına giren res mancipi lerden olan araziyi zikretmek muvafık olur. Nilekim, ikinci fikri güden hukukçuların hepsi mülkiyetin tarihçesinden bahsederken tarihçenin mebdeine res mancipi olan arazi üzerindeki mülkiyeti dahil etmektedirler. Su halde, bu müellifler, dolayısıle olsa bile Romada mülkiyetin en eski devirlerde res mancipi ler üzerinde mevzu bahis olduğunu kabul etmiş addedilebilirler.

2. Mülkiyetin tarihçesi. (28)

Bazı müellifler (29), arazi mülkiyetinin ilk defa kabilelere ait bulunmuş olduğunu, bazıları ise (30), paterin Heredium a sahip bulunmasını ileri sürerek, erazi mülkiyetinin hususi mülkiyete dahil bulunduğunu iddia etmektedirler. Bazı hukukçular da Romada paterin ziraatine terk edilmiş erazi üzerinde hususî gayri menkul mülkiyetinin mutlak olduğu fikrindedirler. (31)

En son Roma hukuku eser (32) ve makalelerinde bile henüz münakașartlar ile dolu olan bu meseleye katiyete yakın bir hal çaresi bulabilmek fikrimizce aşağıdaki ayırdı göz önünde tutarak hükmetmekle mümkündür:

$\left.1^{\circ}\right)$ Romanın çobanlıktan kurtulduğu devre kadar arazi mülkiyetinin hususi mülkiyete değil kabile mülkiyetine dahil olduğunu müdafaa etmek bu hayatın mahiyetine uygundur. Hakikaten, henüz çobanlık devresinde yașa-

(27) - P. Koschaker IZ. der. saw. Stift. 1918. p: 259 et S.); F. de visscher, Mancipium et res mancipi: 1 Studia, 1936. p: 317 et s); R. Monier, Manuel, 1945, t. 1. p: 355 et s. Bu müellifler, res nec mancipi lerin de actio sacrementum in rem ile talep edilmekte ve mülkiyetin gerek res mancipi, gerek res nec mancipi ier için kabul edilmis olduğunu iddia etmektedirier.

(28) - Ed. Cuq, Manuel, 1928, p: 916 et s; P. Collinet, Rev, hsit. de droit. p: 694; Mommsen, Droit public, VI. I. 1889, p: 26 ets; Girard, Manuel, 1928. p: 280 st s; R. Besnier, Rev, hist. de droit, 1934, p: 436 et s.

(29) - Ed. Cua, Monuel, 1928; p: 916; Kaila, L'unité fonciére en droit romai.' 192

(30) - Piganicl, Origines de Rome, 1916, p: 228 et s.

(31) - Il transferimento della Proprietà, 1924. p: 26 el s.

(32) - R. Monier, Manuel, 1945, p: 336 et $s$. 
yan kavimlerde gayri menkul (arazi) üzerinde hususi mülkiyetten bahsetmek umumiyetle mümkün değildir.

$\left.2^{\circ}\right)$ Romada zirai ekonomi hayatı bașladığı tarihden itibaren ferdî eraz: mülkiyetinden bahsetmek yerinde olur. Cünkü bu hayat, hususi mülkiyete zarurî ve kat'i olarak yer verir. (32)

Fakat işaret edelim ki, ziraî ekonomi safhası ile on iki levha kanun rına kadar geçen devrede erazi üzerindeki hususi mülkyieti zilyedlikle beraber giden fili bir mülkiyet olarak kabul etmek, bu devrede hususi mülkiyeti gösterir metin yokluğunun icap ettirdiği zarurî bir mütalâa olur. (34)

Erazi üzerinde tam manası ile hususi mülkiyetin resmen kabulü tarihini așağı yukarı katiyete yakın bir rakamla belirtmek lâzım gelirse, Lex Thoria dan (M. E. 114) bahsetmek lâzımdir. Filhakika, ancak bu kanun ile dir ki Devet erazisi (Ager Publicus) ferdi erazi (Ager privatus) ye inkılâp etmeğe başladı. (35)

II - Mülkiyetin şumulü. ve tahdidi.

1. Mülkiyetin sumulü.

Menkul mülkiyetinin sumulünü belirtmekte güçlük yokłur. Gayri menkuß mülkiyetinin maddi șumülü hudut tayini (limitatio) ile ve sekle riayet edilerek tespit edilmekde idi. Hudut ihtilâfları actio finium regundorum ile hallediliyordu. (36) Erazinin sathı üzerinde yapılan bu tahdit erazinin alt ve üstüne şamil değildi. Binnetice, dominus soli, (gayri menkul maliki) erazinin derinliğine bütün muamelede bulunabilirdi.

(33) -- Romada ziraî ekonomi havatının basłangıc tarihini Roma sehrinir şöle böyle teskilâtlandiğı devirlere kadar çikarmak vanlıs olmaz. Su halde, Romanm bos'angıcından Oniki levha kanunlarina kadar gecen devrede arazi üzerindeki hususi mülkiyeti red eden görüs tarzlarını kabul muvafik düsmez.

(34) -.. Bu mütalâa paterin, aile sefinin tasarufu cimba bulunan agi occupatorii, vani işal edilmiş, zilyedliğe alınm:s Devlet arazisi için devieie muaven bir hasılat vermesi mükellefiveti ile de tevit olunabilir: R. Monier, Manuel, 1945, t. 1. p: 359, No: 259, n: 6 .

(35) - G. Bloch et J. Garcopino, Histoire romaine, t. II. p: 190 et s; 242 et s; A. Pi. ganiol, Annales d’hist. Écon. t. I. 1929, p: 382 et.

Kanun 35 Tribu ve ait araziden Roma vatandașları tarafindan, aile sefleri tarafından isgal edilmis arazi üzerinde hususi mülkiveti tanivordu. Fakat bu kanundan sonra hususi mülkivete cevrilmemiş olan Ager Publicus üzerinden vine vergi alınmava devam olundu: Trapenard, L'Ager Scripturarius, p: 15 et s; 212 et s.

Pleblerin tekrar Romanya've verleşmelerini temin için bunlara arazi, dağıtan Lex Sempronia (M. E. 134) da arazi üzerindeki hususi mülkivetin resmen tanınması için bir mebde olarak zikredilebilir.

(36) - Buckiond, Rev. hist. de droit., 1936, p: 745 et s. 


\section{Mülkiyet hakkinın tahdidi.}

Kirit mülkiyeti hukuki cepeden kısıntıya tâbi değildi. Jus ułendi, jus fruendi ve jus abutendi istenildiği gibi kullanılabilirdi. Binaenaleyh, malik şeyi istediği gibi kullanır, meyvelerini istediği șekilde istihlâk eder ve jus abutendi yi dilediği gibi kullanır, yani şeyi satar ve hattâ tahrip edebilir.

Mamafih, Roma hukukunda bilhassa gayri menkul mülkiyetinin hukuken kısıntılara uğradığını görüyoruz. (37) Bu tahditleri iki bakımdan gözden geçireceğiz :

$\left.1^{\circ}\right)$ Ozel menfaatler dolayısı ile kısıntılar:

Komşu eraziden diğerine ağaç dallarının sarkmasına diğer erazi sahibi muhalefet edemez: komşu erazi sahibi diğer eraziye düșen meyvelerini toplamak için bu eraziye girebilir; komșu erazi sahibi erazisi üzerinde diğer eraziye tehlike getirebilecek hareketlerde bulunamaz.

Bu kısıntılar Oniki levha kanunlarında yazilıdır.

$\left.2^{\circ}\right)$ Genel menfaat namına mülkiyete konan tahditler.

Bu kısıntılar arasında bilhassa șunları anmak lâzımdır: Inşa edilmiş bir binaya dahil, onun mütemmim cüzü haline gelmiş bulunan bir direk, sahibi tarafından sökülüp alınamaz. (38) Malzemesi satılmak için bina tahrip olunamaz. (39) Nihayet, amme menfaati için özel mülkiyete son verilebilir. Ancak bu, Roma hukukunda teknik manasında istimlâk müessesesinin varlığına delil teşkil edemez. Zira, Romada özel mülkiyetin bertaraf edilmesi yalnız savaş harekâtına zarưi olan eraziye inhisar ediyordu: İslâm hukukunun hilâfına olarak, Roma hukukunda istimlâki prensipde teknik bir kaideye bağlayan bir hükme tesadüf olunmamaktadir.

Diğer cihetten ammeye ait bir binanın inşası için gayri menkul mülkiyetine tecavüz edilmiyòrdu. (40) Mamafih, majistraların bazı hallerde kanun veya senato kararına dayanarak erazi sahiplerini erazinin tamaminı veya bir kısmını sałmaya zorlama yetkilerinin mevcudiyetinden Romada teknik ol-

(37) - E. H. Kader, L'exercice de la propriété à la fir de l'époque classique: IRev des études latines, 1937, p: 136 et $\mathrm{s}$.)

(38) - R. Monier, Manuel, 1945. †. I; $\mathrm{p}: 363, n: 1$,

(39) - Girard, Textes, 6 éd. p: 132 et s; May, Rev. hist. de droit, 1935, p: I et s. Sahildeki gavri menkut sohipleri deniz nakil vasıtalrınin ve bilhassa gemilerin iskele ihtiyacını reddedemezler.

(40) - Bonfante, Corso, 11,1.1926, p: 249 et s.

Romada mülkiyete konulan tahditler arasinda işletilmeyen arazinin işal edilebileceŏini: (Ed. Cuq, Manuel, 1928. p: 248), baškasının arazisinde moden oacŏı keşfeden kimsenin bu arazi sahibinin rızasına bile muhtac olmaksızın bunu isletmeqe yetkili bulunmasın: (Ed. Cua, Manuel, 1928. p: 245, n: 4) ve nihayet, gayri menkul sahiplerinin harap vaziyette bulunan evlerini tamir ettirmeleri mükellefiyetini: (R. Monier, Manuel, 1945. †. 1. p: 368, n: 2) kaydetmek läzımdır. 
mamakla beraber istimlâk müessesesinin nüvesini kabul etmek yerinde olur.

III - Mülkiyet çeşitleri.

1. Kirit mülkiyeti. (Dominium ex jure quiritium)

Romalı șeye taalluk eden, Roma vatandașlarına ait ve jus civile ce muteber intikal ve iktisap usullerine göre iktisap edilebilen bir mülkiyet tipidir. Kirit mülkyeti tam manası ile mülkiyet hakkı yaratan, yani hak sahibine ju; utendi, jus fruendi ve jus abutendi yi bahşeden bir mülkiyet tipidir.

A - Kirit mülkiyetinin șartları.

Yukarıdaki tariften anlaşlacağı üzere kirit mülkiyetinin doğumu için ü esaslı șarta lâzımdır:

$\left.1^{\circ}\right)$ Mevzu Romalilara ait bir șey olmalıdır.

$\left.2^{\circ}\right)$ Malik Romalı vatandaş olmalıdır.

$\left.3^{\circ}\right)$ Iktisap jus civile ce muteber usullerden biri ile vaki olmalidir.

Bu üç şarttan birinin yokluğu şahsı, iktisap edeni, sey üzerinde malik değil zilyed kılar.

B - Kibrit mülkiyetinin müeyyidesi.

Kirit mülkiyeti çeşitli davalar ile himaye edilmekte idi. Bu davalar sıras" ile șunlardir:

a) Actio rei vindicatio. (istihkak davası)

Seyin zilyedliğini kaybetmis olan malik bu davaya müracaatla onu 178 - Hukuk dergisi Cilt V - 12 nci makale

geri alabilir. Dava, Justinianus zamanında seyi elinde bulunduran herkese karşı açılabilir. (47)

Ispat külfeti davacıya (malik) düser.

Actio rei vindicatio nun neticeleri Formüllü dava usulü ile fevkalâde yargılama devrinde bazı farklar gösterir.

$\left.1^{\circ}\right)$ Formüllü dava usulü devrinde actio rei vindicatio nun neticeleri: da. vali, şeyi aynen, șey mevcut değilse veya aynen tazminden feragat ediyor. sa nakden iade ile mükellef olduğu gibi miktarı davalının yeminine itimod edilerek tespit edilmis veya edilecek olan zarar ve ziyanı da ödemeye mec.

(41) - Justinianus, Rei vindicatio nun neticelerinden kurtulmak maksad: ile seyi terk eden zilyede, asıl zilyedi zaman asımından faydalandırmak ve onu sev üzerinde malik kılmak maksadı ile kendini zilyed gösteren ve bu suretle davavı kabul eder sahsa kar. \$i da actio rei vindicatio nun açilabileceğini kabul etmiştir: Girard. Mancei, 1929, b: 366, n: s; Ed. Cuq, Manuel, 1928, p: 299. 
burdur. Hüsnüniyetli zilyed, litis contestatio dan sonra vaki ziyadan mesul değildir. (42) Meğerki, şey kusuru ile zayi olmuş olsun, Suiniyetli zilyed kusur haricindeki ziyadan mesul olacağı gibi şey üzerinde litis contestatio dan evvel veya sonra vaki kıymet düşüklükleri ile de mülzemdir.

Formülü dava usulü devrinde actio rei vindicatio semerelerin iadesini sağlamaz.

Hüsnüniyetli zilyed zarurî ve faydalı masrafları tenzil etmeğe haklıdır. Seyin kıymetini artırmayan faydalı masrafların lüks masraflar tenzil edilemez. (43) Suiniyetli zilyed bu masrafları tenzil edemez.

$2^{\circ}$ ) Fevkalâde yargılama usulü devrinde actio rei vindícatio nun neticeleri: Zilyed aynen teslime zorlanabilir; dava litis contestatio dan evvel șeyin semerelerin iadesine de șamildir. Justinianus zarurî masrafların tenzili bakımından her iki zilyed arasında fark gözetmez, hattâ kötü nyietli zilyede bazı faydalı masrafları isteme hakkını bahşeder. (44) Nihayet, Justinianus, jus tollende yi, yani lüks masrafları şeye zarar vermeksizin alma hakkını hüsnü niyetli zilyede odluğu kadar suiniyetli zilyede de tanır. Mamafih, malik, sökülen şeylerin söküldükten sonraki kıymetini vermek veya șey söküldüğü takdirde hiç bir kıymet ifade etmeyeceğini ispat etmek şartı ile jus tollendinin klulanılmasına mani olabilir. (45)

b) Actio negatoria ve actio prohibitoria. (46)

Kirit mülkiyetinin kullanılmasına müdahale edildiği veya mutlak vasfı ihlâl edildiği vakit malikin açacağı dava tipleridir. Actio rei vindicatio malikin zilyedliği kaybetmesi halinde açıldığı halde bu iki davanın açılması zilyedliğin elden çıkmıs olması şartına bağlı değildir.

$\left.1^{\circ}\right)$ Actio negatoria.

Bu dava başkasına ait erazide haksız olarak intifa veya aynî irtifak hakkı kullanılması halinde malik tarafından açılır. Malik, mülkiyetine giren şeyin kanunen bu haklarla takyit edilmis olmadığını iddia ve ispat eder. (47)

(43) - Ed. Cuq, Manuel, 1928, p: 303, n: 6; aksi manada: Bonfante, Corso, 11, 2. p: $308, n: 1$.

(44) - R. Monier, Manuel, 1945, I. p: 376, n: 2.

(45) - Actio rei vindicatio nun teferruatlı neticeleri için: Giffard, Précis, 1934. I. p: $399 \cdot 401$

(46) - R. Monier, Manuel, 1945, 1. p: 370, n: 4; 377, n: 1.

(47) - Her iki dâvado da ispat külfetinin kime tereftüp ettiği kativetle malûm değildir. Bu hususta ileri sürülen fikirler için bakınız: Girard, Manuel, 1929. p: 374, n: 4.

Başkasının arazisinde haksız vere irtifak hakkı kullanmak isteyenin mahkûmiyeti bu hakkı bir daha kullanmamasına dair kendisinden söz almava inhisar eder; bu sözü yerine geirimezse para cezasina carpilir: 1Gaius, Inst. IV. 51). 
$\left.2^{\circ}\right)$ Actio prohibotoria ile malik, erazisi üzerinde bir şey yapmak isteyen sahsın bu filine son verir.

c) Actio ad exhibendum.

Ayni bir dava olup bilhassa maddeten karıșmıs bulunan şeylere istihka$\mathbf{k}_{\mathbf{1}}$ temin eder. (48) Davanın gayesi karıșmıs olan șeyin ayrılması ve bilâhara actio rei vindicatio ile geri alınmasından ibarettir.

Jusinianus, bu davanın suiniyetli inşaat sahipleri aleyhine de açılabileceğini kabul eder. Fakat, inşaata dahil olan şeyin, yapıda kullanılmış olan malzemenin, geri alınması için değil tazmin için kabul edilmiștir.

Kirit mülkiyeti şahsî davalar ile de müeyyidelenmiștir (49):

$\left.1^{\circ}\right)$ Cautio damni infecti.

Cumhuriyet devrinden itibaren erazi sahibi, hatiâ servitüd sahipleri inşaat yapan komşu erazi malikinden inșaat dolayısiyle zarar husulü halinde tazmin edeceğine dair vaadde bulunmasını isteyebiliyorlardı. Bu suretle vaadde bulunmus olmak inşaatın devamına sed çekmenin önüne geçiyordu. Inşaattan zarar gören komșu erazi maliki actio ex stipulatu il ezararın tazminini istiyordu. Vaad tutulmadığı takdirde pretör komșu erazi sahibine inşaatın mülkiyetini bile verebiliyordu.

$2^{\circ}$ ) Interdictum quod vi aut ciam. (50)

Komşu erazi sahibine zarar verici bir yapının kaldırılmasını veya, yapı bitmiş ise, zararın tazminini sağlamak maksadı ile verilen interdictum dur. Ancak, inşaałın komşu erazi sahibinin yasağına (vi) rağmen veya hileli bir sekilde (clam) yapılmıs olması sarttır.

Klâsik devirde bu interdicta ya inşaat müddeinin erazisinde yapılmıș. olduğu, Justinianus devrinde ise inșaatın müddei ve müddeialeyh e ait erazi v̈zerinde kurulmuş bulunduğu halde müracaat edilir.

$\left.3^{\circ}\right)$ Operis novi denuntiatio. (51)

Bir erazi sahibinin erazisi üzerinde diğer erazi veya gayri menkulü zarara sokacak veya harabiyete sevkedecek inşaatda bulunmamasını bildirme-

(48) - Bu dâva actio rei vindicatio dan ekseriva evvel açlitr ve onun bir baslangıcr olarak islerdi: rei vindicatio da bulunmak isteven sahıs sevin hüvivetini ivice anlamak için kendisine ait olup olmadığını pesinen bilmek maksadı ile zilyedi şevi Maiistra önüngetirmeğe zarlad. Demek ki, menkuller hakkindaki istihkak dâvalarinda actio ad exhibendumun açılmas! âdetti.

149) - Ed. Cuc, Manuel, 1928, p: 574 et s;

(50) - R. Monier, Manuel, 1945. †. I. p: 379, $n: 2$.

(5i) - O. Martin, Etudes girard, 1913, t. 1. p: 123 et s. 
si ve bunu yerine getireceğine dair verilen sözün yerine getirilmemesi halinde kom\$u erazi sahibine tanınan davadır.

$\left.4^{\circ}\right)$ Actio aquae pluviae. arcendae.

Hâdim erazi sahibinin hâkim eraziden inen suların mecraını değiștirtmeğe yarayan bu dava Justinianus devrinde mülkiyetten gayri aynî hak sahiplerine de tanındığı gibi, bunların ve hâdim erazi sahibinin hâkim eraziden akan sudan faydalanmalarını da temin eder.

2. Pretör mülkiyeti. (In bonis habere)

A - Pretör mülkyietinin mahiyeti.

Jus civile gereğince bir șey üzerinde tam manası ile mülkiyete sahip olabilmek için o șeyin jus civile nin gösterdiği yol ve şekillerde devredilmiş olması lâzımdır. Aksi takdirde, seyi iktisap eden, jus civile nazarında possessor (zilyed) den ibarettir. Binnetice, rei vindicatio'ya maruz kalarak șeyi iadeye mecbur tutulur. Şey bir semen mukabilinde, yani beyi akdi ile iktisap edilmiş olsa bile, mancipatio veya in jure cessio ya riayet edilmedikçe yapıllan teslim (Traditio) aynı neticeyi doğurur. Bu haksız neticeden ötürü olmalıdır ki pretör res mancipi ye ve Romalı vatandas elinde bulunan res nec mancipi yi devr alan șahsı himaye etmek maksadı ile onu güya şeyi jus civile ce iktisap etmiş gibi farz etmek suretiyle jus civile șekilciliğinin mülkiyet sahasına aks eden bir mahzuru bertaraf etmiștir. Bu suretle șey, onu iktisap edenin mamelekinin aktif kısmına (in bonis) dahil olur. (52)

Pretör mülkiyetine sahip olabilmek, seyin her zaman hüsnü niyetle iktisap edilmis olması şartına bağlı değildir; çünkü pretör mülkiyeti bazan pretör emri ile zorla da iktisap edilir. Bonorum venditio ve bonorum possessio hallerinde hal böyledir.

Bazı müellifler (53) hüsnü niyetli zilyedi pretör mülkiyeti sahibine benzetmekte, bazıları da bu fikri red etmektedirler. (54) Hüsnüniyetli zilyed satıcının asıl malik olduğunu zannederek șeyi alan kimse olduğuna göre. Ve, evvelce de gördüğü üzere, actio rei vindicatio da mülkiyet mevzuunun mutlaka aynen teslimine lüzum bulunmadığından hüsnüniyetli zilyede pretörlerinin bonis habere yi bahssetmeleri isabetsiz bir hareket farzı olamazd. (55)

(52) - Bu itibarladir ki pretör mülkiveti ekseriva Proprété bonitaire tabiri ile ifade olunur: Appleton, Histoire de la propriété prétorienne et de l'action publicienne, II vol. $1889-1890$.

(53) - Ch. Appleton, Proporiété pretorienne, †. 1, $p: 12$.

154) - Ed. Cuq, Manuel, 1928, p: 249, n: 2 et 3; Bonfante, Corso, 11, 2, p: 320, 323.

(55) - Mamafih, nev'i, vasfı ve sıfatı ile tayin edilen seyler hakkında bu fikir istisna toskil edebilir. Meselâ bir kölenin hüsnüniyetli zilyedine köle üzerinde yalnız intifa hak- 
Pretör mülkiyeti res mancipi ve res nec mancipi ler üzerinde caaridir.

B - Pretör mülkiyetinin müeyyideleri.

In bonis habere actio ve exceptio lar ile himaye edilmekte idi

a) Actio publiciana (56)

Menșei ihtilaflı olan ve fakat Sbinus zamanında malum olduğu iddia olunan (57) bu dava ne vakit, hangi devirde yaşadığı belli olmayan Publicius adındaki bir pretör tarafından yaratılmıștır.

Dava, pretör hukukunca mülkiyete sahip olanların, Klâsik devirden itibaren de usucapio ile iktisap yolunda bulunan her zilyedin istihkak davası mahiyetindedir. Jus civile ye uygun olmayarak satılan res mancipi nin müsterisi (zilyed) ve diğer zilyedler bu dava ile şey üzerinde usucapio nun bitiminde jus civile ce mülkiyet hakkı doğuracak olan zilyedliği tekrar elde ederler. Bu gayeye erişebilmek için, pretör, zilyed lehine olmak üzere hâkime güya usucapio müddeti bitmiş, dolmuş gibi hükmetmesini emrediyordu. Bu suretle Publiciana actio ya farazî bir actio rei vindicatio mahiyeti verilmekte idi.

Zilyed gerek hüsnüniyetli, gerek suiniyetli bulunsun, yani res mancipi yi formaliteye uymadan iktisap etmiş olsun, dava formülü aynı idi. (58) Formülde hüsnüniyetin zikrine de lüzum yoktu. (59).

Justinianus hukukunda, kirit ve pretör mülkiyeti ayırdı hemen hemen kalktığından, Publiciana actio yalnız hüsnüniyetli zilyedin zilyedliğini himayeye münhasır kaldı.

Davalı, șeye daha evvel zilyed buunduğunu ispat ederse dava kaybedilir. Meselâ davalı da şeyi davacının satıcısı bulunan asıl malik olmayan kmiseden daha evvel aldığını ispat ederse zilyedlik iade olunmaz. Fakat bu netice pretör mülkiyetinden faydalanan zilyed için mevzu bahis olamaz. Her nekadar, șeyin jus civile ye göre maliki bulunan şahıs exceptio justi dominii yi, yani şeye jus civile ce malik olduğuna dair defii ileri sürülebilirse de, pre-

kı sahibi sıfatını vermek ikfiza ederdi, binnetice, zilyed tarafından yapılan azadı muteber saymak doğru olamazdı.

(56) - Appleton, Histoire de la propriété prétorienne et de l'action publicienne: (Rev, gén. du droit, 1923, p: 161 et s.

(57) -- Girard, Manvel, 1929. p: 375, n: 2,

(58) - Ed. Cuq, Manuel, 1928, p: 304; Girard, Manuel, 1929, p: 376; Giffard, Précis, ง. I. 1938, p: 402, n: 2 .

159) - R. Monier, Manuel, 1945, 1. p: 381 ; Aksi manada: Lenel, Das edictum, 3 éd. p: 179 . 
tör mülkiyeti sahibi bu defiyi replicatio rei venditae ve traditae ile ref edebilir, zira, pretör, mülkyeti șeyin jus civileye uyulmaksızın satılması ve teslim edilmiş olması halinde bahșediliyordu.

Davanın neticeleri prensip itibariyle actio rei vindicatio nun neticeleri gibidir.

b) Pretör mülkiyetini himaye eden exceptio lar.

Pretör mülkiyetini himaye eden exceptio lar daima pretör mülkiyefi malikinin lehine netice doğurur. Çünkü pretörün kendisine mülkiyet hakkı tanıdığı zilyed henüz jus civile ye göre malik durumuna geçmemiștir, ancak bu suretle hak sahibi olmaya pretör tarafindan himaye ile desteklenen bir namzedden ibarettir. Oyle bir namzet ki, usucapio müddetince kirit hukukunca malik addedilmektedir. Su halde, șey üzerinde kirit maliki rei vindicatio da bulunduğu zaman, zilyed (pretör mülkiyeti sahibi) bu iddiaya karșı kirit mükiyetine kat'i namzetlik sıfatını dermeyan suretiyle her zaman galip çıacaktır. Halbuki kirit mülkiyetine sahip olduğunu mücerret zilyede (pretör mülkiyetine sahip olmayan zilyede) karșı dermeyan eden şahıs davayı kazanabilir; çünkü șeyi ona devrettikten sonra yine jus civileye uygun yollardan biri ile tekrar iktisap etmiş olduğu def'inde bulunabilir.

3. Peregrin mükiyeti ve Eyalet erazisi üzerindeki mülkiyet

A - Peregrin mülkiyeti.

Jus commercium a sahip olan yabancılar müstesna, peregrinler dominium ex jure quiritium dan faydalanamazlar. Bununla beraber, pretörler ve Eyalet majistraları bu peregrinlerin de bir şey üzerindeki hakimiyst ve haklarını kirit mülkiyeti neticelerine müncer olan davalar ile himaye ettiler. Bunu temin için pretör hâkime pregrinlerin bazı hallerde, pretör hukukunca meşru sayılan hususlarda, aynen roma vatandaşı muamelesi görmeleri lüzumunu formülde bildiriyordu. (60)

Nihayet, Gaius, peregrinlere hâs mülkiyet hakkından bahsediyor: peregrinler kendi siteleri kanunlarınca mülkiyete sahip olabiliyorlard. (61).

B - Eyalet erazisi üzerindeki mülkiyet. (62)

Prensip itibariyle ve bilhassa ilk devirlerde Italyadaki, ve, sonraları fethedilmiş eyaletlerdeki erazi özel mülkiyete dahil olmayor, amme mülkü

\footnotetext{
(60) - Gaius, Inst. IV, 37.

(61) - Mamafih bu hak Romanın müsaade ettiŏi nisbette muteberdi: Girard, Texte 1937. p: 69.

(29) - Falletti, Evolution de la iuridiction civile du magistrat provincial, p: 45, 85, et s.
} 
(Ager publicus) addediliyordu. Ancak, bu erazide oturup erazi vergisi verenin durumu fili bir malik durumunu ifade ediyordu. (63)

Bazı müellifler (64) ayalet erazisindeki fertlerin bu erazi üzerindeki hakların mülkiyetle alâkası olmadığını iddia etmektedirler Bu fertlere verilen ayni davalar actio re ivindicatio ya benzetilebilirse de, erazi üzerinde ius abutendi yi kullanamayacakları nokłasından hareket edilerek sözü geçen müellifleri takip etmek fikrimizce uygundur. $(65$

IV - Kirit ve pretör mülkiyetinin, ve binnetice, Actio rei vindicatio ve Publiciana actio ayırdının ortadan kalkması.

Justinisnus un iki constitutiones inden biri nudum jus quiritium u, diğeri res mancipi ve res nec mancipi tasnifini ehemmiyetten düșürdüğünden ve bu suretle Italya erazisi ile Eyaletler dahilindeki gayri menkuller arasında da fark kalmayınca, ve nihayet bütün Roma sakinleri de vatandaş sayllınca. Justinianus hukukunda mülkiyet (Propriełas) șekillerinin ortadan kalkmıs olduğu anlaşııır.

Bu surete, Roma ile modern hukuk arasında mülkiyet şekli bakımından bir fark kalmamis oluyor.

Ancak, mülkiyete sahip olmak bakımından iki hukuk arasında bariz farklar vardır ve berdevamdir: Romada ancak vatandaşlar mülkiyete sahip olabilirler, modern hukukda ise yabancılar da mülkiyet hakkına prensip itibariyle sahiptirler. Romada köleler mülkiyetten mahrumdurlar, modern hukukda kölelik mevzubahis omadığından herkes hakka sahpitir.

V - Ferdî ve Kollektif mülkiyet.

1. Ferdî mülkiyet.

Bu paragrafa kadar maliki hep tek bir şahis olarak farz ettik.

Ferdî mülkiyet, șeye hukuken hâkim olan şahsın ius utendi, jus fruendi ve jus abutendiyi prensip itibaryile yalnız kendisi tarafindan kullanılmasını icap ettiren mülkiyet tabiri ile ifade olunabilr.

(63) - Imparatorluk devrinden itibaren Evalet arazisi, Hükümdar ve Roma halkına ait olmak üzere hukuken ikiye ayrıldi. Hūkümdara ait olana. Praedia Tributaria, halka ait arazive de Praedia stipendiaria denir: Gaius, Inst, $11 ; 7,21$.

(64) - Ed. Cu.q, Manuel, 1928, p: 251.

(65) - Aksi manada: R. Monier, Manuel, 1945. 1. 1. p: 366 et $\mathrm{s}$.

Müellif, eyalet arazisinden foydalanma hakkina sahip bulunan ve ona zilved olan ferdin bu arazivi Traditio ile devredebileceŏi hakikatını mütalâasına destek et. mekte ise de, Traditio mülkiyeti dežil, evvelce oörüldüŏũ üzere mülkiyetin iktibası için, 
2. Kollektif mülkiyet. (66) (Dominium communio)

Kollektif mülkiyet jus uttendi, jus fruendi ve hattâ jus abutendiyi en az iki şahsa veren bir mülkiyet tipidir.

En eski Roma hukuku göz önünde tutulursa bu tarifin yerinde olduğuna hükmedilir, çünkü Cumhuriyetin son senelerine kadar Roma hukukunda müșterek mülkiyete sahip olanlar, socius (șerik) ler şeyin tamamı üzerinde mülkiyete sahip idiler (67), yani șey üzerinde ferdî mülkyiet hükümleri caari idi. (68)

Cumhuriyet devri sonlarından itibaren her socius un ancak kendi hissesi üzerinde jus abutendi yi kullanabileceği kabul edilmek suretiyle eski sistem değiști: șeyin tamamen, bütünün devri diğer socus lerin rızasına bağlıdır. (69)

A - Socius un hakları ve diğer şeriklerle münasebeti.

$\left.1^{\circ}\right)$ Her socius müșterek mülkiyet üzerinde diğer șeriklerin haklarını ihlâl etmemek şartı ile semerelerden hissesi nisbetinde faydalanabilir, binnetice,

$\left.2^{\circ}\right)$ Bütün şeriklerin jus utendi sini ihlâi edecek olan, meselâ, müșterek eraziye bina yapilbmaz.

$\left.3^{\circ}\right)$ Müșterek mülkü tamir ettiren socius diğer şerikler tarafından tazmine müstahaktır. (70)

B - Müşłerek malikler arasındaki münasebtin müeyyidesi.

Bazı müellifler Justinianus devrinden evvel de bu hususda aynî mahi

daha doğrusu intikali için lâzım gelen hukukî imkânı, muhiti varatır. Diğer cihetten, evalet arazisinden favdalanan șahsın bu arazi üzerindeki zilyedliğini özel hukukdaki zilvedliğe benzetmek doğru değildir. Zira, traditio ile elden ele geçen evalet, arazisine hâkim her zilyed vergivi ödemekle mükelleftir? Su halde, eyalet arazisinde hakkı olan fertlerin zilvedliğini nevi şahsına münhasır bir zilyedlik olarak mütalâa etmek verinde olur.

(66) - Collinet, Rev. hist, de droit, 1932, p: 597; Jaen Caudement, Etudes sur le régime iuridiaue de l'indivision, Strasbourg, 1934, p: 525.

(67) - Collinet, Rev, hist. de droit, 1934, p: i06; R. Monier Les nouveaux fragments des intitudes de Gaius, 1933, p: 24 et $s ;$ J. Gaudement, da geçen eser, p: 18 ;

(68) - Mamafih, her socius un kendi başına kölevi satması veva azâd etmesinin imkân dahilinde olduğunu iddia etmek lâzımdır. Aksi manada: R. Monier, Manuel, 1945, t. I. $p ; 370 \mathrm{n}: 3$

(69) - Justinianus, socius a, diğerlerinin hissesine düseni eda sartı ile, müsterek mülkiyete dahil kölevi azâd etme selâhiyetini verdi: J. Macqueron, La controverse classique sur le ius aderscendi en matière d'affranchissement: (Rev. hist. de droit, 1929, p: 580 et s.)

(70 - Marcus Aurelius tazmine iștirak etmeven serikin mülkiyet hakkından mahrum dilceğini kabul etmiști: D. 17, 2, fr. 52, 10. 
yette bir șirket akdi davasının mevcudiyetini ileri sürmektedirler. (71) Sirket akdinin müeyyidesi olan actio pro socio yu mukaveleden doğan müşterek mülkiyetin müeyyidesi olarak kabul etmek yerindedir.

Justinianus hukukunda actio communi dividundo serikler arasındaki münasebeti teyid ve tanzim eder. Dava, hisselerin ayrılmasını temin ettiği gibi, bir serikin kusurundan zarar görmüs olan diğer șerikleri tazminata da müstahak kılar.

VI - Mülkiyet hakkının ziyaı.

Sahsi haklara, alacak haklarına aykırı olarak, mülkiyet hakkı daimilik gösterir, yani șey devam ettiği müddetce hak bakîdir. Bu takdirde mülkiyet hakkının ancak șahıs değisstirmesi mevzubahis olur. Prensip bu olmakla beraber mülkiyet hakkı gerek maddî, gerek hukukî bazı sebepler ile ortadan kalkabilir.

1. Mülkiyet hakkını ortadan kaldıran, ziyaa uğratan maddî sebepler.

Bu sebepler șunlardir:

$1^{\circ}$ ) Mevzuun tamamiyle zayi olması. Kısmen ziya halinde, mülkiyet geri kalan kısım üzerinde berdevamdır.

$\left.2^{\circ}\right)$ Bir ehli hayvanın kaçıp bir daha dönmesinin mümkün bulunmayısı. Bu takdirde hayvan ya ölmüștür, veya vahșileșip av hayvanları zümresine dahil olarak res mullius a inkilâp etmiștir. (72)

$\left.3^{\circ}\right)$ Res mancipi veya res nec mancipi nin sahibi tarafindan istekle terk edilmiş olması da bunlar üzerindeki mülkiyet hakkının ziyai neticesini verir.

2. Mülkiyet hakkının hukuki sebepler ile ziyaı.

Res privata nın res divini humani juris lerden res religiosase ye çevrilmis, inkilâp etmiş olması bu milkiyetin, ferdî mülkiyet hakkının hukuki sebepler ile ziyaına misal olarak gösterilebilir. Res privatae nin res publica haline geçmesi şey üzerindeki özel mülkiyet hakkının daimî ziyaına sebep olmayabilir.

\footnotetext{
(71) - Poisnel, Nouv. Rev. hist., 1879, p: 420 ef s;

Bzaı müellifler de aynı neticeyi istisnaî hallere inhisar ettirmektedirler: R. Monier Monuel, 1945, 1. p: 371 et s,

(72) -- Sabinienlerin bu fikri Proculienlerce su sartla muteberdi: terk edilen şev diğer bir sahıs tarafından iktisap edilıniş olmadikça ilk malikin mülkivet hakkı sönmemiștir. Julien Sabinienlerin fikrini takip etmiş ise de, Proculienlerin fikrini kabul daha dağrudur, cünkü, rıza ile terk eden sahıs o sevin zilyedine karssı zaman aşımından evvel actio rei vindicatioyu açabilmek yetkisine sahıptir. Bu vetki Usuccpio veva praescriptio için kabul edilmis olan müddetin son bulması anında ortadan kalkar ki, bu da ilk malikin mül. kivet hakkının zevali manasını ifade eder.
} 
Cünkü bu takdirde, șey, amme mamelekine, devlet patrimoniun una dahil, ve binnetice, mülkiyetin sahip değiștirmesi mevzubahis olur.

Mülkyiet mevzuunun mülkiyetin iktisabı veya intikali yollarından biri ile devredilmiş olması, mülkiyet hakkının ziyaına değil, sahip değiştirmesine yol açar. Bu neticenin husulü için Roma hukukunda da kaide şudur: Intikal iskatî ecele veya infisahî șarta bağlı olarak yapılamaz. (73) Bu kaide mülkiyet hakkının daimiyet vasfının makul bir neticesidir. (74)

Justinianus hukukunda bu kaidenin hibe, fidsicommissum ile istisnalara uğradığı görülmektedir.

Uçüncü Fasıl.

\section{Z I L Y E D L I K}

(Possessio)

Mülkiyet hakkından farklı olarak, zilyedlik bir șey üzerinde hukukî değil filî bir hâkimiyettir. Bu prensibin tek istisnası aslî zilyedlikde mevzu bahistir.

1 - Zilyedliğin menşei ve tarifi.

1. Zilyedliğin menșei. (75)

Zilyedliğin menșeini ararken mülkiyetin menşeine de temas etmek ve bundan netice çıkarmak zarurîdir. Paulus (76) gibi bazı Roma hukukçularının bu gün itibarda olamayacağı katiyetle belirtilemeyen fikirlerine uyarak zilyedliğin Proprietas dan evvel mevcut olduğunu kabul eṫmek lâzımdir. Filhakika, Romada mülkiyet kabul edilinciye kadar Roma vatandașlarının devlete ait erazide vergi vermekle adetâ malik durumunda bulunduklarını görmüsstök. Fakat hakikatle bunlar proprietas a değil, rekabe (çıplak mülkiyet) Devlete kaldığı cihetle, bu arazi üzerinde Usus ve ususfructus (istimal ve intifa) haklarına sahip olduklarından, hukukî durumları vazulyedinkinden, yani possessio naturalis in yarattığı durumdan farksızdır.

Su halde, Roma hukuku tarihine hâkim olmuş nazariyeden hareket edilirse, ilk zamanlarda Romada possessio nun mevcudiyetini ve hattâ proprieetasa tekaddüm ettiğini kabul etmemek mülkiyetin menşei hakkındaki sarih tarihî bilginin mevsukiyetini inkâr etmek olur.

(73) - P. Coilinet, Etudes historiques sur le droil de Justinien, t. I., 1912, p: 174 et $\mathrm{s}$.

(74) - E. Petit, Mélanges Cornil, II. 1926, p: 210 et s.

(75) - Westrup, Rev. Hist. de droit. 1933, p: 224; Giffard, Précis, t. 1. p: 366, n: 1.

(76) $-D, 41,2$, fr. 1, 2; 
Mamafih, poessessio nun menșeini onun proprietasa karine teșkil eden bir müessese olduğunu hesaba katarak araş̧ırıc bir sistem takip edilirse, yokarıdaki mütalea kıymetini kaybeder, ve bu takdirde, zilyedliğin menșeini mülkiyetin tanınmıs olduğu tarihe kadar indirmek iktiza eder.

2. Zilyedliğin tarifi.

Zilyedlik, bir șey üzerinde ona malik olmak niyeti ile kurulan fili hakimiyettir.

Bu tariften zilyedliğin ekseriya onunla beraber giden ve bu cihetten zahiren ona benzeyen mülkiyetle, seyin filen bir bașkası elinde kalmasına mahal veren vazulyedlikten ayırd edilmesi zarureti doğar.

$\left.1^{\circ}\right)$ Zilyedliğin mülkiyetten farkı.

Mülkiyet bir șey üzerinde hukukî hakimiyetin ifadesi olduğundan şeyin daima malik elinde bulunmasını icap ettirmez. Halbuki zilyedliğin ispałı ekseriya şeye maddeten hâkim bulunmakla mümkündür.

$2^{\circ}$ ) Zilyedlikle vazulyedlik arasindaki fark.

Zavulyed, zilyedliğin teșekkülü, iktisabı için gerekli unsurlardan olan animus a sahip değildir. Binnetice, șey üzerinde prensip itibariyle Jus abutendi den faydalanamaz. Hırsız, çalınan șey üzerinde zilyeddir, cünkü şeyi mamelekine dahil etmek için, șeye olmak niyeti ile ona el koymuștur. Buna mukabil, meselâ, fuzulî vekil (Negotiorum gestor) vazulyeddir.

II - Zilyedliğin tarihçe ve çeșitleri.

Roma, șey üzerindeki her fili hâkimiyeti zilyedlik nazariyesi içinde mütaâla etmiş ve Roma hukuk tarihi boyunca bu nazariyeye itibar olunarak çeșitli zilyedlik tipleri kabul edilmiştir.

1. Klâsik devirde zilyedlik tipleri.

A - Possessio civilis.

Justa causa ya dayanan ve şey üzerinde kirit mülkiyetini yaratan filî bir hakimiyettir. Zilyed, aşağı yukarı pretör hukukunca malik durumundadır, ve, interdicta larla himaye görür.

B - Possessio ad interdicta.

Sey üzerinde ancak ve ancak filî hâkimiyete sahip bulunduklarını iddia eden șahısların zilyedliğidir. Bunlar, bu itibarla, zilyedliği himaye eden interdicta larla himaye görümüşlerdir. Bunların şey üzerindeki hakimiyetleri seyi iktisap için değildir. Șu halde, possessor cviilis, animus possidendi ye, 
bunlar ise yalnız mücerret zilyedliğe sahip olan kimselerdir, ve himaye edilmiş olmaları, șey ellerinde bulunduğundandır. (77)

C - Possessio naturalis.

Bir şahısla bir şey arasındaki az çok devamlı filî her münasebeti ifade eder. Possessio naturalis tam manası ile possessio olmayıp, zilyede (Possessor naturalis) sey üzernide filî bir faydalanma imkânı bahsedebilir; halbu ki Possessio ad interdictada zilyed (possessor pro possessor) sey üzerinde intifa hakkına da sahiptir. Alieni juris lerin, Depositumda vedia alanın zilyedlikleri bu nevidendir.

Possessio corporalis (possessio naturalis) zilyed lehine mülkiyete karine olmadığından (78) zilyedliği himaye eden interdicta ları bahşetmez. Possessio corporalis (vazulyedlik) de iki kısma ayrilı:

a) Muhik sebebe dayanmayan vazulyedlik.

b) Muhim bir sebebe dayanan possessio naturalis.

Ikincisine misal olarak rehinle temin edilmiş alacaklının vazulyedliği ileri sürülebilir. (79)

2. Justinianus hukukunda zilyedlik ve tipleri.

Justinianus ıslâhat yapmak isterken possessio yu daha karıșık hale koymuștur: Justinianus possessio civilis ve possessio naturalis taksimini devam ettirmiş olmakla beraber possessio ad interdicta yı birinci kategoriye dahil eylemiş, ve nihayet, bazı hallerde vazulyedliği de interdicta lar ile himaye etmiștir.

III - Zilyedliğin iktisap ve ziyaı.

1. Zilyedliğin iktisabı. (80)

Bir şeyin zilyedliğine sahip olabilmek için zilyedliğin manevi unsuru olan Animus ile maddî unsurunu teșkil eden Corpus un bir şahısda toplanması lâzımdır.

(77) - Bu çeşit zilyedler arasında, bâtıl bir muamele ile şevi elinde bulunduranları da dahil edilmekte idi: D, 24, 1, fr. 26, pr.; Dumont, Les donations entre époux, 1928; p: 43 et $s$ : Karı koca arasındaki hibe mevzuu bunlardan birinin zilyedliăi altına girebilivordu.

(78) - Bövle olunca, vazulyedlikle possessio içtima edebilir: Gaius, Inst. IV. 153; D, 41,5 , fr. 2, pr.

(79) - D. 9, 4, fr, 22, 1; R. Monier, Manuel, 1945, t. 1, p: 389, n: 1.

(80) - Saleilles, Efudes sur les éléments constitutifs de la possession: (Rev. bourguinonne, 1894, †. 4.1; Thering. Rôle de la volonté daris la possession, 1891 ; Micolier, Pécule et capacité patrimaniale, $1932, p: 542$ et s. 


\section{A - Corpus.}

Roma hukukunda, bilhassa ilk devirlerde, Corpus un elde edilebilmesi için şahsın (zilyed namzedi) bizatihi șeye filen hâkim olması lâzımdı. Sonraları șeyi temsil eden bir vasıtanın da Corpus u nakledebileceği kabul edildi, hattâ gayri menkulün corpus u traditio brevi manu ile de, yani erazi hududunun el ile işaret edilmiş olması ile de tesis edilebiliyordu.

Corpus un mutlaka zilyed tarafından temin edilmesine lüzum yoktur. (81) alieni juris ler pater, procurator lar ve vasiler, vekil (mandator) ve fuzuli vekil (negotiorum gestor) müekkilleri için copus u elde edebilirler. (82)

B - Animus.

Klâsik devir hukukçuları himayeye müstahak hukukî manada bir possessio dan bahsedebilmek için zilyedin animus unsuruna sahip olmasını şart koşarlar. (83)

Mamafih, Așağı Imparatorluk devrinden itibaren zilyedliğin iktisabı için mutlaka corpus unsuruna lüzum bulunmadığına sahit oluyoruz. Filhakika, icarda mucir vazulyedden, yani possessor corporalis den ibarettir ve kiralarken tam bir zilyed olmayı düșünmemiștir. Netice itibariyle, kiraya veren corpus a sahip olmadığı halde kiralanan șeyin zilyedidir. (84)

Justunianus hukukunda, hukukî manası ile possessio Savigny nin görüs tarzına hâkim animus un mevcudiyeti ile muteberdir. (85)

2. Zilyedliğin ziyaı.

Corpus ve animus unsurlarından her ikisinin veya bunlardan yalınız birinin elden çıması zilyedliğin ortadan kalkmasını doğurur:

(81) - Paulus, Sent. V. 2. D. 41, 3, fr, 41; Le Bras, l'évolution générale du procurateur, 1922, p: 88 et $\mathrm{s}$.

182) - Giffard, Précis, 1934, t. 1, p: 340, no: 570; R. Monier, Manuel, 1945, t. 1. p: 390 , $n: 3$

(83) Animusun rrahiveti Savignv ile Ihering münakasasına vol açmıstır: Savigny ve göre zilyeden cunimus domini've, Thering'e göre ise animus possidendi ve sahip olmasi lâzımdır. Animus domini zilveden sev üzerinde malik gibi hareket etmesi ve kontrolda bulunmasın icap ettirir. Animus possidendi sırf seyin muhafaza edilmesi istek ve nivetini ifade eder. Modern mevzuatın ekserisi thering görüsünü kabul etmis bulunmaktadir: Giffard, Précis t. 1. p: 351 et s) bu tesiri etrafı ile izah etmiștir.

(84) - D. 13, fr. 37 .

Zamanımız hukukunda kirava verenin corpusu tapu sicili vasıtası ile tecelli eder.

(85) - R. Monier, Manuel, t. I. p: 391, n: 5 . 
A - Corpus un ziyaı ile zilyedliğin son bulması.

$\left.1^{\circ}\right)$ Seyin zilyed tarafından istekle terk edilmesi. Istekle terk, hiç değilse terk anında animus dan da vaz geçmeyi ifade edeceğinden zilyedlik șeyin terki ile ortadan kalkar.

$\left.2^{\circ}\right)$ Corpus un daimi surette ve istek haricinde elden çkması halinde de animus mevcut olmasına rağmen zilyedlik ortadan kalkar.

$\left.3^{\circ}\right)$ Klâsik devir hukuku, bilhassa ziraati teşvik maksadı ile, erazi üzerindeki ihmali corpus un ziyaına benzetmiștir. Mamafih, hileli occupatio seyin mülkiyetini iktisaba elvermez, ve bilhassa, bir erazinin bir kısmında corpus devam ederken diğer kısmında efmemiş olması bu kısım üzerinde occupatio ya mahal vermez. (86)

Justinianus hukukunda possessio jure (hukukî zilyedlik) animus unsuru ile tahakkuk edeceğinden, corpus un ziyaı ehemmiyetsizdir. Corpus un ziyaı zilyedin arzusu veya fiili ile vuku bulmadıkça, zilyedlik bakidir. Binaenaleyh, gaiplik ve savașda esir düșmüș olmak ancak vazulyedliğin ziyaına sebep olur, zilyedliği kaldırmaz. (87)

IV - Zilyedliği himaye eden interdictum lar ve bunların mahiyeti.

1. Zilyedliği himaye eden interdiler. (88)

Zilyedliği himaye eden interdicta lar ya zilyedlik mevzuunun elden çımamasını, veya elden çıkmış olan zilyedliğin tekrar iktisabını sağlarlar.

A - Zilyedliğin elden çıkmamasını sağlayan interdiler.

a) Interdictum uti possidetis. (89)

Bu enterdiler gayri menkuller üzerindeki zilyedliği himaye ederler. (90)

b) Interdictum utrubi.

Menkuller üzerindeki zilyedliği himaye edici enterdilerdir. Bunlar, Justinianus dan evvel, elden çıkmış olan zilyedliğin himayesini, tekrar elde et-

(86) - Teferruat için: Albertario, Rev. hisł. de droî, 1931, p: 20 et $s$.

Meraların üzerinde corpus un kıs mevsiminde mevcut olmavısı, ve şey üzerinde corpusun muvakkaten kalkmıs bulunması zilvedliğin zevali neticesini vermez: D. 43,16 fr 1, 24; Paulus, Sent. V. 2, 1.

[87) - Mamafih, seyin zorla gasbı zilyedliğe son verir: D. 43, 16, fr. 1, 24.

(88) -- Alelâde vazulvedlik actio injuriarum ile himcve edilivordu: R. Monier, Manul. 1945, t. 1. p: $393, \mathrm{n}: 8$.

(89) - Girard, Textes, p: 165, n: 247.

(90) - Goius, Inst, 4. 151. 
mesini sağlamakda idi iseler de Justinianus interdictum utribi nin de interdictum possidetis gibi şeyin corpus $u$ elde bulunduğu hallerde istenebileceğini kabul etti. (91)

B - Zilyedliğin tekrar elde edilmesini sağlayan enterdiler.

(Interdictum recuperande possessionis causa)

Bu interdictum lar üç tiptir:

a) Interdictum unde vi.

Justinianus devrinde bir sene içinde kullanılması kararlaștırılan, kabul edilmiş olan, ve bir çeșit gösteren bu interdictum Klâsik devirde iki çeșit idi:

$\left.1^{\circ}\right)$ Interdictum unde vi cottidiana.

Erazi üzerindeki meşru zilyedliği zorla alınmıs șahıs lehine verilen enterdir.

$2^{\circ}$ ) Interdictum unde vi armata.

Zilyedliği silâh kullanarak elinden alınmış şahıs lehine verilen bir enterdidir.

Bu iki enterdi arasındaki fark șudur: sonuncusunda zilyedlik meșru olmasa bile zilyed himaye edilir.

b) Interdictum de precario.

Zilyedlik mevzuunu talebi üzerine eline geçirmiş olup da iade etmeyen şahıs aleyhine verilen enterdidir. (92)

c) Interdcitum de clandestina possessione.

Zilyedin yokluğundan, gaybubetinden faydalanarak seyi alan şahsa karși verilen enterdidir.

Imparatorluk devri actio momentariae possessionis i kabul etmekle zilyedliği aşağı yukarı mülkiyet gibi, ve hattâ mülkiyetten daha kuvvetli bir surette himaye etmiştir. (93) Dava otuz senelik bir müddet içinde açוlır.

2. Zilyedliği himaye eden enterdilerin mahiyeti.

Pretör hukukunda zilyedliğin himaye edilmesinin sebebi büyük münakaşalar doğurmuștur. (94)

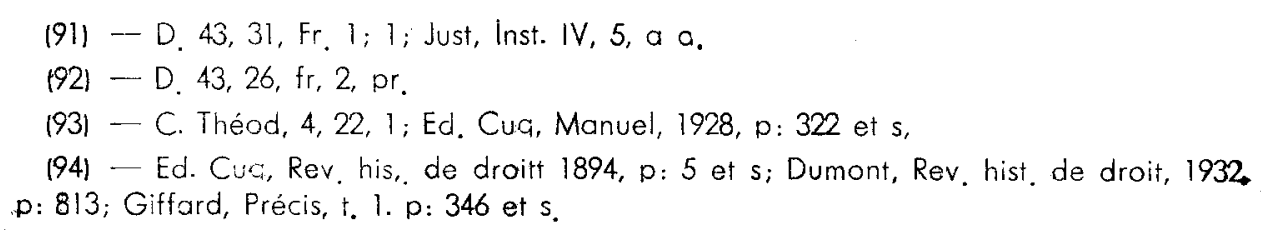


Zilyedliği himaye eden enterdilerin mahiyeti hakkında iki sistem çarPışmış̦ır:

a) Savigny sistemi. (95)

Sawigny, ziyedliği himaye eden enterdilerin amme intizamın temin etmek, şahsan ihkakı hakkın doğuracağı fenalıkların önün egeçilmesi için verilmiş majistra emirlerinden ibaret bulunduğu fikrindedir.

b) lhering sistemi. (96)

lhering, enterdilerin mahiyetini zilyedliğin mülkiyete karine olması noktasından hareket ederek hal eder, ve bu enterdilerin bahşedilmesine mülkiyetin himaye edilmesi mülâhazasının hâkim olduğunu ileri sürer. Ihering e göre, zilyedlik mülkiyetinin karinesidir, ispat külfetini zilyede yüklemez, binaenaleyh, bu büyük menfaat pretörce himaye edilmek istenmiştir.

Her iki sistemin mantık bakımından olduğu kadar hukuk bakımından da isabetli olduğunda şüphe yoktur. Fakat hukukî cepeden hangisi hakikate daha yakındır? Bizce, zilyedliğin ispatına dair kat'î karineler daima mevcut olacağından, mülkiyetin ispatı için ise bu aşağı yukarı imkânsız bulunacağından (çünkü mülkiyet zilyedlikle kuvveden file çıkar) Sawigny nin fikri daha isabetlidir. Zilyed ekseriya seyi elinde buundurduğundan mülkiyetin karinesi Corpus a hâkim bulunmakla esasen garantilenmiş demektir.

Ihering'in görüs tarzını Roma hukuku bakımından da katiyetle kabul etmek hayli güçtür, çünkü, Romada possesio, propriétas kabul edilmeden evvel de mevcuttu ve enterdiler ile himaye edilmekte idi. (97) Nihayet, enterdilerden hakikatte malik olmayan hirsızlar, gasıplar da faydalanırlar. (98)

Metinlerde thering in fikrine yer veren hükümler varsa da bunların da isabetsizliği açığa vurulmaktadır. (99)

Digesta, «Quieta non movere: sükûneti ihlâl etmemek» hükmünü koymakla Sawigny ye hak vermis oluyor.

Dördüncü Fasıl.

\section{Mülkiyetin iktisabı}

I - Mülkiyetin iktisabı yollarının tasnifi.

Iktisap yolları çeșitli ve ihtilâflı tasnife tâbi tutulmuștur.

(95) - Traité de la possession, éd, 1803, fransizca tercümesi: 1886.

(96) - Fondement de la protectio porsessoire, 1865; Oeuvres choisis, 1893, p: 213 et s..

(97) - R. Monier, Manuel, 1945, t. 1, p: 384, n: 5 .

198) - Giffard, Précis, 1934, t. 1 p: 347, No: 585.

199) - Giffard, Précis, 1934, †. 1; p: 348, n: 1 , 
Roma hukukuna uygun düşebilecek olan taksimin șu suretle yapılması ekseriyetce muvafik bulunmaktadır:

1. Jus civile ye göre iktisap yolları.

Bunlar, Mancipatio, in jure cessio, usucapio, adjudicatio ve kanundan ibarettir. (100)

Jus civile nin tanıdığı mülkiyetin iktisap yolları șekliyetcidir.

2. Jus gentium ca muteber iktisap yolları.

Sekliyetci olmayan ve Romalı olmayanlara olduğu kadar Roma vatandaşları lehine de ișleyen iktisap usulleridir. En başta Traditio yu ihtiva eden bu yollarla kirit mülkiyeti değil, peregrin ve eyalet erazisi üzerindeki mülkiyet iktisap edilir. Occupatio da bu kategoriye giren iktisap yollarından biridir.

Her iki kategoriye dahil iktisap yollarının müșterek vasıfları:

Gerek jus civile, gerekse jus gentium a ait iktisap yolları ile mülkiyete sahip olabilmek için aşağıdaki şartlar müșterek ve lâzımdır.

$\left.1^{\circ}\right)$ Seyi devreden mülkiyete sahip olmalıdır, ona sahip bulunmalıdır. kaide bu olmakla beraber zarurî istisnalar mevcuttur: delinin kayımı, kendisine ait olmayan șeyi devredebilir.

Her irâdî intikal șeklinde aşağı yukarı șekilcilik vardır.

II - Jus civileye ait iktisap yolları.

1. Mancipatio. (101)

Sahsın hukukunda da rolleri görülmüș olan Mancipatio çok geniş șumulde bir hukukî muamele usulï, șekli, kalıbıdır.

Burada Mancipatio yu ancak mulkiyetin intikal usulü olduğu nisbef dahilinde tetkik edẹceğiz.

A - Mancipatio nun șekli ve tarihçesi.

a) Mancipatio nun șekli.

(100) - Girard, Marvel, p: 305, no: 548; Georgesco, Rev. hist. de droì, 16. 4, p: 427, $n: 1$ :

(101) - Dvelet tarafindan yapilan intikalieri jus civile ye mulâk olarak dahil etmek fikrimizce doğru değildir; zira, devletin gerek vatandaşlar ve gerekse vabancilar ile muamelede bulunmas! mevzuu bahistir, ve bu muamelât jus civile intikal usulleri ile vaki olmaz. Devletin müracaat ettiği intikal usulieri de bu sebepierden ötürü, bazı müelliflere muhalif olarak: Girard, p: 305, No: 548; Giffard, Précis, t. 1. 1934, p: 355; No: 5931 ius gentium usulleri arasında mütalâa ermek daha doğrudur. 
Mancipatio bir terazi ve maden külçesini tartan libripens $i$, ve nihayet, erkek ve baliğ beș șahidin huzurunu icap ettirir. (102)

Devredilecek șeyin veya sembolün de mevcudiyeti șarttır:

Mancipatio da aktif rol devr alacak olan şahısdadır. Bu, devredilecek şeyin kiritler hukukunca kendisine aił olduğunu bildirir bir formül kullanırdı. Bu formülü beyandan sonra şeyi devralacak olan șahıs hakikî' veya farazi bir semen de tayin ederdi; bunun üzerine Libripens teraziyi ona uzatır ve möșteri, elindeki maden külçesi ile teraziye vurduktan sonra șey libripens tarafından kendisine verilirdi.

b) Mancipatio nun tarihçesi.

Klâsik devirde mancipatio hakiki ve peșin bir beyi muamelesi idi. (103)

Para, maden külçesi ile temsil olunmaktan kurtulduğu devirde mancipatio yapmacık, farazî bir beyi muamelesine inkılâp etti. (104) Mamafih, mancipatiodaki bu değișikliğin tarihini kesin olarak beyan imkânsızdır. Bu hususda Mr. Girard, Oniki levha kanununun metnine dayanmakla meseleyi müsbet ve tarihî bir hakikatle ispat etmektedir. (105)

Bu suretle mücerret bir muamele haline geçmiş olan mancipatio nun tatbik sahası da genișledi: hakiki bir beyi den sonra şeyin devrini sağlayan bir usul olarak tatbik edildi. Ivazsız intikallerde de kullanıldı (hibe gibi). Aynî garantilerin tessiinde de rol aldı.

B - Mancipatio ile devredilebilen seyler.

Gaius (106), kirit mülkiyetinin iktisap ve intikaline yarayan mancipatio nun tatbik sahasını tahdit etmiștir: res mancipi ler mancipatio ile devredilirler.

(102) - H. Lévy - Bruhl, La formule vindictoire: (Rev, hist; de droit, 1932, p: 206); R. Besnier, Rev. hist. de droit, 1934, p: 456 et s.

(103) - Mancipatio muamelesinde huzuru lâzım bes sahit hususunda fikir ayrılikları mevcuttur: bazılarına göre bu şahitler şevi devredenin satıs akdine rıza göstermek üzere getirdiği aile efrodındandır. Bazı müelifflerce (Giffard, précis, 1. p:359, n: 3) sahitler gentilis veya vicinilerden ibarei olup kefil rolünü ovnarlar. Mr. Leifer, 1936, p: 66 et s. sahitlerin sevin devrine rıza göstermekle mükellefi bulunduklar fikrindedir. Mancipotio yazilı bir muamele olmadiğindan sahitlerin rolünün muamelevi tevsik etmekten ibaret bulunduŏuna hükmetmek lâzımdır.

$1104)$ - Giffard, Précis, t. 1. p: 359. Aksi manada: R. Monier, Manuel, 1945, t. 1. p: 405

$1105)$ - Ed. Cuq, Manuel, 1928, p: 273.

(106) - Girard, Manuel, p: 300: Cum riexum faciet mancipium que, uti ligua nuncupassit, ita ius esto: tartma olmasa bile sey tarafların bevanı ile intikal eder; aksi manado Appleton, Rev. Général de droit, 1921. 
Mamafih, Klâsik devirde inci, elmas gibi kıymetli res nec mancipiler ile Eyalet erazisinin de mancipatio ile devredildiği metinlerden anlaşılmaktadır. (107) Bu sonuncu halde, eraziden bir sembol hazır bulunmalidır. (108)

C - Mancipationun neticeleri ve tatbik sahasından kalkıșı.

a) Mancipationun neticeleri.

$\left.1^{\circ}\right)$ Seyi iktisap edene kirit mülkiyetini nakleder. (109)

$2^{\circ}$ ) Auctor, șeyi devreden, eski hukuk devrinden itibaren şeyin gizli ayıplarından mesuldür. Auctor, bilhassa gayrin mamelekine dahil bir șeyi devretmiş ise iki mükellefiyete maruzdur:

Müșteriye karșı açılacak olan rei vindicatio da onu müdafaa etmek. Uçüncü şahıs (malik) davayı kazandığı takdirde satıcı (auctor) actio auctoritatis ile semenin iki misline mahkûm olur.

Seyin servitüd ile mükellef olmadığına dair yapılan beyanın sahteliği halinde, auctor, actio de modo agri ye maruz kalır ve semenin iki mislini öder.

b) Mancipatio nun tatbik sahasından kalkışı.

Așağı Imparatorluk devrinde mancipatio nun sözden ibaret bir muamele tipi olarak kaldığı görülmektedir. Mancipatio yazılı bir muamele şeklini aldı ve eski usul üzere farazî tartma ve seklî merasim ortadan kalkłı.

justinianus hukukunda res mancipi ve res nec mancipi taksimi ehemmiyetini resmen kaybetmis olmakla mancipatio, mevkiini filen Traditio ya terk etmiştir. Nihayet, Justinianus mancipatio yu resmen kaldırdı. 110)

2. In jure cessio.

A - In jure cessio nun menşei.

Bazı müellifler bu iktisap. usulünün Romada mülkiyetin iktisabına ait hiç bir usulün mevcut olmadığı devirlerde tatbik edilmekte olduğu kanaatindedirler. (111)

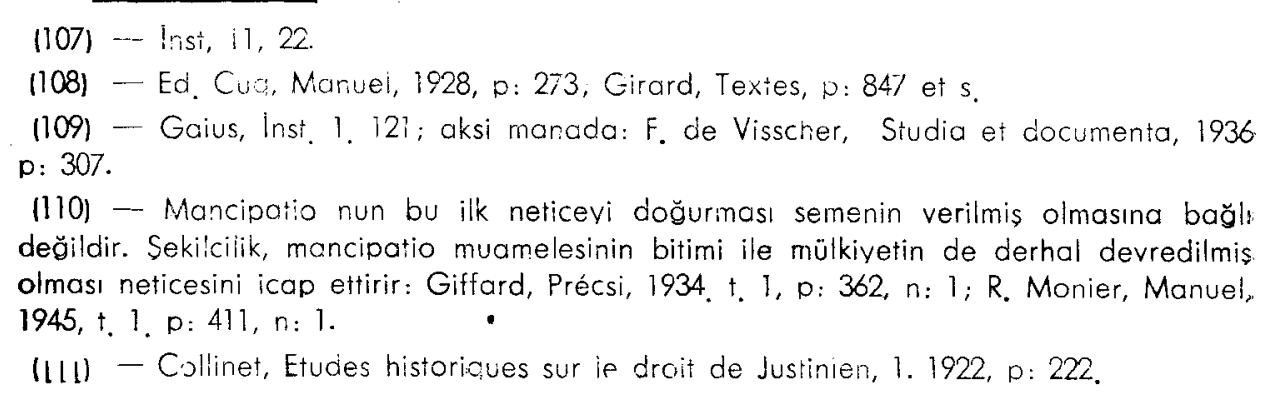


Bazı hukukçular in jure cessio nun mancipatio kadar eski bir usul olduğunu müspet deliller ile ileri sürmektedirler. Mr. Giffard, in jure cessio nun siteyi ilgilendirecek kadar ehemmiyetli intikallerde tatbik edildiği fikrindedir. Bu fikri in jure cessio nun menşeine esas tutmak yerindedir. Hakikaten, mancipatio yanında ayriyeten in jure cessio gibi ve majistra huzurunda ceryan eden bir usulün menşeini ararken bașka mülâhazatın derpiși, bizce, daha cok isabetli olamazd. (112)

Bazı hukukçular in jure cessio yu farazi bir dava mahiyetinde mütaláa ederler: seyi devredecek olan sahis maiistra huzurunda susar ve devr alacak olan Sacramentum in rem darası ile seyin mülkiyetini iddia eder, bu iddia üzerine Majistra seyin mülkyietini iddiada bulunana devr emrini verir.

Hukukçuların ekserisi bu görüş tarzına muhaliftir. Bunlarca, in jure cessio majistra önünde oynanan bir komedi değildir: seyi devredecek olan sahıs maiistra tarafindan dinlenir ve conta vindicatio da bulunup bulunmayacağı öğrenilir; yoksa majistra sırf seyi devr alacak olan tarafın iddiası üzerine şeyin mülkiyetini devr emrini vermez. (113)

Su halde in jure cessio yu hakiki bir legis actio seklinde ceryan eden bir usul olarak mütalâa etmek yeni tetkiklerin ciabından olur.

C - In jure cessio nun tatbik sahası ve neticeleri.

a) In jure cessio nun tatbik edildiği haller.

Mancipatio dan farklı olarak, in jure cessio hem res mancipi, hem res nec mancipi lerin devrini sağlar.

b) In jure cessio nun neticeleri.

Mancipatio ya muhalif olarak, in jure cessio ile șeyi devreden sahıs sonradan cıkacak mesuliyeti mucip hallerden dolayı takibe maruz değildir. Hattâ devredilen sey ona ait olmasa bile aleyhine açlacak hiç bir dava mevzu bahis olamaz. (114).

D - In jure cessio nun tatbik alanından kaldırılması.

In jure cessio daima majistra huzurunda ceryan eden bir usul olduğun-

(112) - R. Besnier. Rev, hist. de droit, 1935, p: 458 et s; Meylon, Rev. hist de droit 1935, o: $77 i$ et $s$; gibi müellifler in iure cessio nun müikivetin intikal usullerı henüz yaratılmamis olon devirlerde majistra, kendisine mülkiyeti terk edilmis olan sahıs lehine su terk muamelesini tastik edivordu. In iure cessio, mancipatio tatbik mevkiinde iken yine tatbik alanında bulunmus olduǒundan müelliflerin fikrine mesnet olan görüs taizı doăru deăildir.

(113) - Giffard, Précis, 1934, t. 1; p: 365, n: 2.

(114) - H. Lévy - Bruh!, La formule vindicatoire; (Rev. hist. de droit, 1932, p: 215 
dan pratik değildi. Klâsik devir hukukunda, ancak Traditio ve Mancipatio ile devrine imkân bulunmayan intifa gibi bazı irtifak haklarının tesisine inhisar etti.

Dioclétien devrinden itibaren in jure cessio tatbik sahasından tamamiyle kalktı.

III - Jus gentium un tanıdığı iktisap yolları.

1. Traditio.

A - Traditio nun tarihçesi.

Tradere (teslim etmek) fiilinden müştak traditio bir şeyin diğer bir șahsa hiç bir șekil ve merasime lüzum olmaksızın verilmiş olması suretiyle mülkiyetin naklini sağlayan bir usuldür.

Oniki levha kanunu Traditio yolu ile satilan res nec mancipinin, semen ödenmiş olmak şartı ile, mülkiyetinin intikal edeceğini kabul eder.

Eski hukuk devri sonlarından itibaren Traditio res nec mancipi ler üzerindeki kirit mülkiyetinin de devrini sağlayan bir usul halinde geldi.

Nihayet, pretör, actio publiciana yı kabul etmekle res mancipi lerin de Traditio ile devredilmesini mümkün kıldı.

Eyalet erazisinin de Traditio ile devri kabul ecilmek :uretiyle, Traditio nun tatbik sahası genișledi.

B - Traditio nun şartlari.

$1^{\circ}$ ) Șeyin bilfiil teslim edilmesi lâzımdır.

Eski hukukda teslim fiilen olmalı idi. Menkuller tamamen teslim edilmeli idi. Gayri menkullerde iktisap edecek olanın bütün erazide dolaştırılması gerekiyordu. (115)

Mamafih, Klâsik devir hukuku aşağıdaki Traditio şekillerine yer vermiş olmakla bu sonuncu teslim zorluğunu kaldırdı :

a) Traditio longa manu.

Bir erazinin devri için tradens accipiens e yüksek bir yerden erazinin hududunu e lile gösterir ve o eraziyi ona devrettiğini beyan eylerse traditio muteberdir.

$1115)$ - Manafih, bu neticelerin ivazsız inłikallerde cari olduğunu kabul etmek lâzın. dir : R. Monier, Manuel, 1945, t. 1. p: 406, n: A. 
b) Temsilî Traditio.

Bir evin anahtarı verilmek suretiyle traditio muteberdir. (116)

c) Traditio brevi manu.

Accipiens in alelâde vazulyødliğini hakiki possessio ya tahvil eden traditio tipidir. Meselâ sey, ona vazulyed bulunan kimseye devredilmek isteniyorsa, traditio nun filen yapılmasına lüzum yoktur. Bu takdirde tredensin, seyi devredenin rızası kâfidir. Su halde, traditio bervi manu da yalnız animus un nakli kâfidir.

d) Traditio instrumenti.

Justinianus hukukunda kabul edilmiş olduğu münakaşalı bulunan bu tip traditio ile şeyi temsil eden vesikaların, senetlerin devri bunların temsil ettiği şeyin de devrini sağlar. (117)

$\left.2^{\circ}\right)$ Causa traditionis. (118).

Traditio ile mülkiyetin intikali yalnız șeyin teslim edilmiș olması ile mümkün değildir. Paulus (119) bunu teyid etmektedir.

Traditio, hukuken borç doğuran bir sebeple - meselâ trampa, çehiz tesisi, hibe, ödeme - vaki olmuş olmalıdır. Aksi takdirde accipiens alelâde bir vazulyed durumundadır, yani traditio mülkiyeti nakletmiş olmaz. Işaret edelim ki hukuken borç doğuran her sebep causa traditionis yerine geçmez: borç doğuran sebep meşru olmalıdır. Binaenaleyh, hukuken tanınmış olup da tradens ile accipiens arasında hüküm ifade etmeyen hukukî sebepier traditio ile mülkiyet intikalini sağlamazlar. Meselâ kan koca arasındaki hibe justa causa traditionis $i$ ifade etmez.

Su halde traditio daki hukukî sebep ona tekaddüm edẹn hukukî ve meşru bir muameleden ibarettir. (120)

(116) - Su halde, tradere kelimesinin valniz teslim etmek manas!na deà birakmick, müsaade etmek manasına da geleceği mahzursuzdur: M. Philıppın, Mélages Mahcim, 1935, t. $\mathrm{l} ; \mathrm{p}: 221$ et $\mathrm{s}$.

Menkullerin traditio ile intikalinde tradens in : "tâka zilyed olması lâzımdır. Gayri menkullerin intikalinde ise buno lüzum olmayacc: baidir.

(117) - Just, Inst. 2, 145.

(118) - Ed. Cuf. Manuel, 1928, p: 269; Giffard, Précis, 1934. †. 1. p: 368, n: 1

(119) - A. Eherhardt, Justa causa traditionis, 1930; R. Monier, Le malentendu sur la causa traditionis: (Studi Bonfante. Ill. p: 217 et s).

(120) -- Paui, D., 41, 1, 31 pr; Gaius, last. 11. 20. 
Justa causa traditionis in butlanı traditio ile intikali bâtıl kılmaz. Ancak, bu takdirde, tradens lehine şahsi bir davadan ibaret olan condictio ob turpem veya condictio in debiti veriliyordu. (121)

Causa traditionis in mahiyetinde vuku bulan anlaşamamazlığın traditi yu hükümsüz kılacağına hükmetmek lâzımdır. Filhakika, justa causa traditionis traditio ile intikalin esaslı sartıdır. (122) Netice itibariyle, tradens seyin teslimini beyi maksadı ile yapmıs, accipiens de şeyi iare zannı ile almıs, kabul etmis olsa, mülkiyet intikal etmis sayilamaz; tradens hibe maksadı ile hareket etmiş olsa bile hüküm aynidır. (123)

Justinianus hukukunda iusta causa traditionis üzerindeki ihtilâf nazara alınmaz. Binnetice, tradens in devri, accipiens in tesellüm arzusu intikalin muteber olsması için kâfidir. (124)

C - Traditio nun neticeleri.

Mancipatio gibi traditio da şeyin mülkiyetini prensip itibariyle derhal nakleder. Fakat, mancipatio dan farklı olarak, şeyin teslimi gerek talikî şart gerekse talikî ecel ile geciktirilebilir.

2. Devlet mallarının intikali. (125)

Devletle fert arasındaki muamele de jus gentium a dahil iktisap yollanndandır, ve hiç değilse, yabancılar mevzuubahis bulunduğu zaman hal böyledir. Devletin vatandaşlarla olan münasebeti, mülkiyetin intikali bakımından tamamiyle jus civile usulleri ile vaki olmus sayilmaz. Zira, Devlet vasandaşlara bir șeyin intikalini jus civile nin âmir hükümlerine uyarak yapmak mecburiyetinde değildi.

Diğer cihetten, Roma devleti icabında zor kuvveti ile de fertlerin mamelekine müdahale edebiliyordu.

Roma devleti fetihlerle genişleyip erazi ve köle bolluğuna kavuștuğu devirlerde fertle devletin karsslıklı rızaya müstenit mülkiyetin intikali yollannın fazlaaşsığı göze çarpar: Devlet savas esirlerini ve ganimet malları vatandaşlara satmakla bu mallar üzerinde kirit mülkiyeti teessüs ediyordu. Bundan basska Senato para ihtiyacını gidermek maksadıyla Devlete ait binaları da sattırabiliyordu. (126)

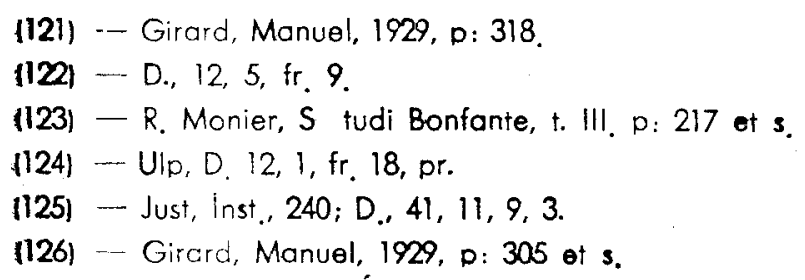


Buraya kadar mülkiyetin iki tarafın iradesi ile iktisabı yollarını tetkik ettik.

IV - Tek taraflı iradeye dayanan mülkiyetin intikali yolları.

Umumiyetle, iki tarafın iradesine dayanan mülkiyetin iktisap yollan haricinde kalan intikal usulleri iktisap edenin ve kanun vazının iradesine müstenit yollar olmak üzere ikiye ayrılır. Itiraf edelim ki böyle bir tasnif mantikıdır. Filhakika, bazı hallerde iktisap edenin iradesi rol oynamaksızın da, mülkiyet sırf kanun hükmü ile iktisap olunur veya intikal eder; terekenin intikali ve taksimi ile mirascının veya mirasciların iktisabı, ve nihayet selâhiyeti yine kanundan olan hakimin mülkiyeti dair verdiği karar kanuni intikal yollarının bâriz misalleridir.

Bu itibarla tek tarafın iradesine müstenit iktisap yolları ile kanun hükmünce iktisap yollarını ayrı ayrı paragraflarda tẹkik etmeyi doğru ve zarurî bulduk.

Birtarafin iradesine dayanan iktisap yolları şunlardır: Occopatio, define, Usucapio, Praescriptio.

1. Birtarafın iradesine bağlı iktişap yolları.

\section{Occupatio.}

Hiç kimseye ait olmayan șeyler (Res nullius) in iktisabı usuludür.

Occopatio ya mevzu teșkil edecek olan selyler Romada'sunlardir.. Mağlüp ordu efradına ait olup Roma vatandaşlarının ellerine geçen menkuller (127), av hayvanlari da res mpllis dur (128). Istekle terk edilen seyler de occupatio ile iktisapolunabilir. (129) Deniz veya nehir veya irmak kenarlarındaki kıymetli maden ve taşlar da res nullius gurubuna dahildir.

2. Define (Thesaurus) (130)

Çok eski zamanlardan beri aranmadığından sahipsiz olduklarına hükmedilen gizli kıymetlerdir.

(127) -- Ed, Cuq, Manuel, 1928, p: 258.

(128) - Ganimet, res nullius değildir: Gaius, Inst. 11. 69; Toutoulon, Rev. d'hist. du droit, 1924, p: 208 et $s$.

(129) - lik zamarilarda havvan avlayanın mülkiyetine gecmis sayilirdı, Klsik devirde vurulan havvanın zilvedliğine de sahip olmak sartı koșuldu: D. 41, I. fr. 51.

(130) - Res cerelictae nin iktisabı ihtilâflıdır; Justinianus iktisap edilebileceŏini (lnst. 2. 1, 47), bazı metinlerde ise terk edilen seyin terk eden tarafindan umuma karsı yapılan bir traditio da bulunmus olduğuna dair hükūm vardır: D. 4I, 7, 5. Binaenaleyh, sey ihrez edileceŏi ana kadar terk edenin mülkiyetinde kalmıs saytlır. 
Cumhuriyet devri sonlarında yetișen laik hukukçular defineyi içinde bulunduğu gayri menkulün cüzü mütemmimi addederler. Imparatorluk devri bașlarından Hadrianusa kadar define Devletin mamelekine dahil edildi. Hadrianus, kendi gayri menkulünde define bulanı malik saydı, ve gayrin erazisinde kazara define bulmuş olan șahsa yarı mülkiyet hakkını tanıd. (131)

Bazı değişikliklere uğradıktan sonra, define, Justinianus hukukunda Hadrianus kaidelerine tabi tutuldu.

3. Usucapio. ve Praescriptio.

A - Usucapio.

Bir șeyin zilyedliğini muayyen bir müddetle elde bulundurmakla o șey üzerinde mülkiyet hakkı yaratan bir iktisap usulüdür.

Occupatio ile usucapio arasındaki bariz fark, birincisinin sahipsiz mallar, ikincisnn malk bulunan șeyler üzernde mevzu bahis oluşudur.

a) Usucapionun tarihçesi.

Oniki levha kanunları erazinin iki, menkullerin bir sene zilyedliğine sahip olunmuş bulunmakla o şeylerin iktisap edileceğini kabul eder. Binaların da usucapio ile iktisabı mümkündür. (132)

Usucapio kirit mülkiyetinin iktisabına yaradığından yabancılar lehine işlyen bir usul değildir, ve Eyalet erazisine de tatbik olunamaz.

Oniki levha kanunu usucapio sartlarını saymamıs, ancak usucapio nun tarbik alanını göstermekle iktifa etmiștir: Mezarlar önündeki küçük arsalar, kadinlar vasinin rizası olmaksızın devrettikleri res mancipi ler (133), nihayet çalınmış şeyler usucapio ile iktisap olunamazlar. (134)

Lex Atinia (M. E. 2) bu şeyler üzerinde ancak alelade vazulyetlik mevzu bahis olabileceğini tasrih eder. (135)

(131) Bonfante (Mélanges Girard, 1. 1912, p: 123 et s, Appleton (Studi Bonfarte, III, - : 3 ef 5 .

(132) - Define devlef arazisinde bulunduğu zaman hüküm avnıdır: İnst, 11, 1, 39. Definenin mahiveti ihtilâflıdır: Ed, 'Cua, Manuel, 1928, p: 280. Define kâsife de hak bahsettiŏinden res nullius addedilmelidir. Ve yine bu sebepten dolayı, kanunî iktisap yollarından da sayilmalidir.

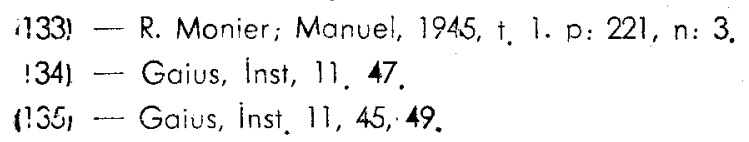


Diğer iktisap yollarının zuhurundan sonra usucop'o bilhassa işlenmemiș halde bırakılan erazinin iktisabını sağlıyordu. (136)

Imparatorluk devri bașlarında çıan lex Plautia ve lex Julia zorla elde edilmiş erazi üzerinde usucapionun netice doğuramayacağını hükme bağlamak suretiyle usucapionun şartlarını belirtmiş oldu: Justa causa ve hüsnüniyet.

b) Usucapionun sartları.

$\left.1^{\circ}\right)$ Justa causa adquirendi. (167)

Usúcapio ile iktisap için șeyin muteber bir hukukî muamele ile zilyedliğine sahip olmuș olmak lâzımdır.

Lusta causa çeșitli ihtimallere göre değişir: zilyed șeye yraditio ile hâkim olmuşsa, justa causa traditiodaki gibidir. Zilyed, seye bizzat el koymus olabilir, bu taktirde iusta causa pretörün emri olabilir. Nihayet, bazı hallerde, justa causa hukukî bir fiil olabilir: Zilyed, terk edilmiş bir eraziye hâkim bulunduğu zaman hal böyledir. (138)

Justa causanın mevcudiyetini ispat zilyede düșer.

$\left.2^{\circ}\right)$ Hüsnüniyet.

Usucapiens'in șeyi asıl malikinden aldığını ve malikin şeyi devre ehil bulunduğunu bilmiş olması veya bildiğini samimiyetle zan etmiş olması lâzımdır. Hüsnüniyet, justa causa sı beyi akdinden ibaret olan usucapioda (usucapio pro emptio) yalnız usucapio başlangıcından değil, beyi akdinin inikadı anında da lâzımdır. (139) Zilyedin bilâhara suniyetli duruma düșmesi usucapio yu hükümsüz kılmaz. 140) (141)

Suiniyetin ispatı müddeiye düșer. Hüsnüniyet daima var farz olunur.

\footnotetext{
(136) - P. Huvelin, Le furtum, 1915, p: 255 et s; De visscher, Rev, hist. de droit. 1933, D: 617 et $s$.

(137) - F. de Visscher, Rev, hist, de droit, 1933, p: 630 et s. Giffard, Précis, †. i. p: 376 n, 1 (138) - Oven, Rev. d'hist. du droit, 1. 16. 4, p: 434 et s.

(139) - Pomponius, D. 41, 3, fr. 29. Sahipsiz tereke üzerindeki usucapio nun justa causa sını asıl mirascısının terekeyi iktisap etmemesi hâdisesi iie izah ediyor.

Justa causa o kadar ehemmivetli bir unsur idi ki, Klâsik devir hukukcuları usucapio yu iusta causa va göre tasnif etmislerdir: Usucapio pro emptor (beyi sebebi ile usucapio,l usucapio pro legato, ı'sucapıo, pro herede ilâh: gibi. Sebebi evvelce tesbit edilemeven usucapio ya usucapio pro suo denir: Albertario, Studia et documenta, 1935, 11. p: 266 et s. (140) - Giffard, Précis, 1934. t. Ip: 380, n: 1.

(141) - Mamafih, bakını: M. Levet, Rev. hist. de droit, 1933, p: 1. Müellif, hibe dolayisıyle usucapioda hüsnüniyetin devamliliğ fikrindedir.
} 
$\left.3^{\circ}\right)$ Zilyedlik muayyen bir müddet devam etmiş olmalıdır. Bu müddet menkuller için bir, gayri menkuller için iki senedir.

Usucapio müddeti içinde zilyedlik inkıtaa oğramamış olmalıdır. Aksi takdirde, müddet yeni baștan doldurulmuş olacaktır. Eski hukuk devrinde, malik şeyi kullanmaya başlamış olmakla usucapio yu inkıtaa oğratabiliyordu. Klâsik devirde hukukî inkıta yerine tabiî inkıta kabul edildi. Mamafih, pretör, küçükleri reśtitutio in integrum ile himaye edebilirdi.

B - Praescriptio.

a) Praescriptio longi temporis. (142)

Usucapio bilhassa eyalet erazisinin iktisabını temin edemiyordu. Bu boşluğu doldurmak için Imparatorlar uzun sureli bir possessio !longae possessionis) manasına gelen praescriptio longi temporisi kabul ettiler. Ilk defa Sévère ve caracalla (199) zamanında Eyalet erazisinin iktisabı için ișleyen P. longi temporis, sonları, Antonin Caracalla devrinde, menkullerin iktisabında ve péregrinler lehine olmak üzere sumüllü bir tarbik sahası buldu. (143)

Yunan hukukundan alinmıx olan praescriptio, usucapio gibi iktisabî mürurzaman mahiyetinde olmayıp, uzun zaman işlenmemis erazinin zilyedine muhtemel bir actio rei vindicatio ya karșı defi hakkı veren bir vasıtadan ibarettir. Yani, zilyede zilyed bulunduğu şey üzerinde muayyen müddet için açılacak davaları red hakkı verir. Binnetice, bu müddet hululünde şey başa bir şahıs eline geçmiş ise asıl malik actio rei vindicatio ile bu zilyede karşı hareket edebilir ve șeyi geri alabilir. Su halde müesseseye iktisabî mürur zaman mahiyetini vermemek gerektir: Praescriptio longi temporis iktisabî mürurzaman olsa idi, asıl malikin actio rei vindicatio ya müracaat hakkı mahfuz olamazdı.

Aısıl malki olduğunu iddia eden şahsın ve zilyedin aynı şehirde ikamet edip etmemesine göre, müddet 10 ve 20 sene olmak üzere tesbit edilmiştir.

Asıl malik bu müddetler son bulmadan actio rei vindicatio ya müracaat etmiş ise, Praescriptio kesilir, ve şeyin yeniden zaptı lâzım gelir.

Praescriptio nun ihdas sebebi 10 veya 20 sene içinde sahibi tarafindan takip edilmemis olan şeyler üzerinde mülkiyet hakkı iddiasında bulunmanın mantıksızlığı düşüncesinden ibarettir.

(142) -- Mamafih, Gaius (Inst. 11, 53), hüsnünivet unsuruna lüzum göstermeven usucapio hallerinden de bahsetmektedir.

(143) -- Bonfante, Corso, 11. 2, 212 et s; Ed. Cuq Manuel, 1928, p: 287 et s. 
b) Praescriptio longissimi temporis.

Praescriptio longi temporis'e yalnız bir müdafaa vasıtalığı rolü vermenin mantıksızliğı anlaşılmıs ve Imparatorlar müddeti uzatmakla ıskatî mürurzamanı ifade eden Praescriptio longissimi temporis i yaratmısłardır.

Bidayetde 40, bilâhara 30 sene müddetle bir şeye zilyed bulunan sahsa karșı açılacak istihkak davası redolunur. Praescriptio longissimi temporis usucapio gibi iktisabî mürurzaman mahiyetinde olmadığından, müddetin bitimi ile şey üzerindeki aynî takyidat da sukut eder.

c) Iktisabî mürurzaman.

Justinianus, usucapio ile praescriptio kaidelerini az çok birleștirmek suretiyle iktisabî mürurzamana da yer verdi: 531 de çıkardığı bir kanunla praescriptio longi temporis i bütün gayrı menkullerin iktisabına yarayacağını ilân etti, ve eski 10 ve 20 senelik müddetler yanında hüsnüniyet ve muhik sebebi de sart koştu. Men

Menkullerin iktisabı için üç senelik müddete tâbi bir usucapio nun devamını kabul etti.

Justinianus, hüsnüniyet ve muhik sebep bulunmayan hallerde praescriptio longissimi temporis in 30 sene olarak devamın kabul etti. Demek ki, justinianus devrinde ikîsabî mürüruzaman usucapio ile praescriptio longi temporis in birleşmesi ile vücut buldu: Menkuller 3, gayri menkuller 10 ve 20 senelik iktisabî mürurzamana (praescriptio longi temporis) tâbidir.

Modern hukuk, bilhassa hüsniniyet unsurunu aradığından ve menkuller için daha uzun süreli zaman aşımı prensibini güłmüs olduğundan, Roma hukukundaki iktisabî mürurzaman sistemi ile ilgisi mevcuttur.

$\checkmark$ - Kanunî iktisap yollari.

1. Accessio.

2. Specificatio.

3. Semerlerin iktisabı.

4. Hâkim hükmü ile iktisap. (Adjudicatio)

1. Accessio.

A - Accessio nun tarif ve mahiyeti.

Aslî addedilen bir șeyle ferî̀ addolunan diğer bir şeyin birbirine karısması ve iktisadî bakımdan basit bir şey meydana getirmeleri haline accessio denir. Maddeten karısma accessio değildir. (144)

(144) - Ed. Cuq, Manuel, 1928, p: 289, n: 5 . 


\section{B - Accessio çeșitleri:}

a) Gayri menkulün bir gayri menkul ile karıșması.

Bir eraziye nehirlerin eklediği toprak parçaları ile o erzî arasında accessio mevzubahistir. Roma, hududu tahdit edilmiş erazi hakkında bu çeșif accessio yu kabul etmiyordu. Binaenaleyh, hudutlar haricinde kalan ek erazinin ancak occupatio ile iktisap edilebileceğini kabul eyliyordu. (145)

İnhidam halinde ağaçlar diğer erazide kök salmıș olmadıkça accessio hükümlerine tâbi değildir.

b) Bir menkulün bir gayri menkul ile karıșması.

Bir eraziye ağaç dikmek, bir arsa üzerinde inșaatta bulunmak bu ikinci accessio haline misal olarak verilmekdedir. Birinci halde ağaç kökleşmedikçe accessio mevzubahis değildir. Ikinci halde, yani bir erczi üzerine bir ev yapılması veya bir evin başkasına ait malzeme ile inşa edilmiş olması halinde malzeme ve bina eski sahibinin malı olmakda devam eder. Ancak, Onik: levha kanunu binanın malzeme sahibi tarafindan yıkılmasını men eder. (146)

Görüliivor ki, bu hallerde tam manası ile accessio mevzu bahis değildir.

Justinianus, başkasının erazısıne suiniyetle malzemesi ile inșaatda bul.ynmus olandan $r$ kiyet hakkını kaldirrak suretiyle vaziyeti tam manası ile accessioya çevirmiștir. (147)

c) Menkulün menkul ile karışması.

Bir kalasın bir gemide kullanılmış olması buna misaldır. Bu halde șeyin mülkiyetinin kime ait olacağı hususunda Sabinienler ile Proculienler arasında ihtilâf mevcuitu: sonunculara göre aslî șey iktisadî ve sosyal kıymeti üstün bulunandır, binnetice, gemi sahibi gëminin cüzü mütemmimi haline gelmiş olan şeye de malik olmalıdır. Sabinienler șeyin maddeten büyüklüğünü kıstas tutmaktadırlar. Justinianus Proculienlerin fikrini tatbik sahasına koydu. (148) Proculien mektebine göre, başkasına ait kâat veya tahta üzerine yazılanı yazının, ve dolayısı ile, tahta veya kâadın mülkiyeti de yazıyı yazana aittir. (149)

(145) - Meselâ bir direğin bir evin inşasında kullanılmış olması halinde accessio mevzubahs olamaz, çünkü ev vikılınca direk sahibi direŏi aynen geri alabilir.

(146) -- Ed. Cus, Manuel, 1928, p: 261.

(147) - D. 6, 1. 23, 7 ve fr. 50

(148) - Sust, Inst. 11, 1, 30 .

(149) - Mamcíih bu görüs tarzının bazı mahzurları olboilir: Girard, Manuel, 1929, p: $35 i$. 
2. Specificatio. (150)

Başkasına ait malizeme ile yeni bir șey (nova spcies) yaratmakdır, üzümle șıra, şarap, sirke, veya, mermer veya bașka bir taşla heykel vesaire yapmak gibi.

Nova species in kime ait olacağı da Sabinien ve proculienler arasında münakaxa edildi: Sabinienlerce, specificatio asıl șeyin cevheri aslîsine, özüne halel getirmis olmayacağından nova speciesin mülkiyeti malzeme sahibine aittir: meselâ, sirke üzüm sahibine ait olacaktır. Proculien melttebine göre ise nova species müstakil iktisadî ve içtima' bir değeri haiz olduguundan, mülkiyet ona vücut verene bahşolunmalıdır. Yeni șeyi meydana getirenin hüsnüniyetli -suiniyetli olmasının tesiri yokdur.

Bizans hukuku, mütavassıt bir hal çaresi kabul etti: Eğer malzeme yeni seyden tekrar elde edilebiliyorsa nova cipecies e vücut veren șey sahibi istihkak davasında bulunabilir: Bakırla sahan yapılması halinde hüküm böyledir. Mevaddı ibdidaiye eski haline çevrilemezse mülkiyet emek sahibinindir.

3. Semerelerin iktisabı. (151)

Semeler, Romada kâh kanunî, kâh fer'î yollar ile iktisap olunur. Filhakika, mülkiyet sahibinin semereleri iktisabı kanunî, intifa hakkı sahibinin iktisabı ise fer'îdir: Intifa hakkı sahibinin semereleri iktisap hakkı mülk sahibi ile aralarında yapılan mukaveleden doğmaktadır. (152)

Intifa hakkı sahibi, semereleri, toplamış olmakla iktisap eder. Binnetice, semerelerin derlenmelerinden evvel çalınmış olmaları halinde actio rei vindicatio yu açacak olan, seyin malikidir. Halbuki, emphytéose da bu davayı açacak olan müstecirdir.

Semerelerin iktisabı meselesinde intifa hakkı sahibinin hüsnüniyetli olup olmamasının ehemmiyeti vardır: Eski hukukda hüsnüniyetli zilyed semereleri usucapio ile (1 sene) iktisap ediyordu. Müddet semeresinin alındığı günden başlar. Imparatorluk devrinde ise ayrılma hadisesi ile semereler. ayrılmıs oldukları andan itibaren iktisap olunur (153) Justinianus devrinde, hüsnüniyetli zilyed mevcut semereleri iade ile mükelleftir.

1150) - Sabinienlerden olmasına rağmen Gaius bu hal çeresini kabul eder: etmis:: (Inst 11. 77-78) Iustinionus da tunda.1 mïlhem olmustur: (Inst, 11, 1, 33-34).

(151) - R. Piccard, Recherchers sur l'hist. de la spécification, Thèse, Lausann 1926.

(152) - Ramelet L'acqusitio des fruits, Lausanne, 1945.

(153) - Debrav, Nouv. Rev. hist. 1909, p: 666 et s. 
4. Hâkim hükmü ile iktisap yolları.

Hâkim, majistradan aldığı formül üzerine mülkiyeti intikal ettirebilir. Buna Romada üç halde tesadüf olunur:

A - Actio communi dividundo. (154)

Müsterek mülkiyet mevzuunun șerikler arasında hâkim tarafından taksimi davasıdır. Burada intikal edecek olan hisse hâkim tarafındạn tayin edildiğinden hâkim hükmü ile iktisap mevzu bahistir.

B - Actio familiae erciscundae.

Mirasın taksimi davasıdır. Mirasın taksiminde de hâkim bazı malların șu bazılarının bu mirascıya devrine yetkili olduğundan, dava hâkim hükmü il intikale müncer olur.

$\mathrm{C}-$ Actia finium regundorum.

Hudut tayin ve tahdidi suretiyle hâkim iki komşu arasında gayri menkul mülkiyetini, ihtilâflı bulunan erazi kısmını devre yetkilidir. 2)

$\mathrm{VI}$ - Kanun hüksnü ile mülkiyetin iktisabı yolları.

Buraya kadar tetkik ettiğimiz bütün iktisap ve intikal yolları haddi zatında hep kanun hükmü iledir. Filhakika, kanun iki sahsın irade beyanına mülkiyetin intikali neticesíni tanımamıs olsa idi, ve tek tarafin iradesini yine bötle bir neticeye bağlayıcı hüküm ihtiva etmemiş bulunsa idi, ne aslì iktisap ve nede feri iktisap yollarindan bahsedilebilirdi.

Bizce, Tam manası ile kanunî iktisap yolu mülkiyet hakkna kanunen son verilen ve başkasının mülkiyetini diğerine nakleden teșri kuvvet iradesinden doğar: Meselâ, lex caducaria nın çocuksuz ve bekâr kimselerin miras hisselerini diğer mirascilara devretmesi, ve, definenin doğrudan doaruya devlete nakli tam manası ile kanunî iktisap ve intikal yollarının tipik misalleridir.

Bundan bakașka, mirastan iskat, iskart edilenin hissesini diğer mirascl- lara devir neticesine müncer olacağından tam manası ile kanunî iktisaba yol açan bir müesseseden ibarettir.

Bu izahattan anlaşıllyor ki, mülkiyetin ikfisap ve intikal yollarının bütün menuel lerde tek taraflı, iki tarafı ilâh gibi kategorilere ayrılmış bulunmasını sırf tedris kolaylığını temin edici bir hareket tarzı, bir sistem olarak mütalâa etmekde mahzur yoktur.

(154) - Mamafih, semerelerin iktisabı anında hüsnüniyetin devamı şarttı: Giffard, Précis, t. 1. p: 392 . 
Besinci Fasıl.

Mülkiyetten gayrı aynî haklar.

(Jura in re aliena)

1 - Giriș.

Başkasına (155) ait şeyler üzerinde bir șey veya şahıs lehine tanınmış olan haklara mülkiyetten gayri ayni haklar denir. Intifak hakları adıle anılan bu haklar mülkiyetten ve şahsî (alacak) haklarından farklıdırlar:

$\left.1^{\circ}\right)$ Mülkiyetden ayrıdırlar, çünki hak sahibi jus abutendi ye sahip değildir. Halbuki bir seyin maliki bu hakka da sahiptir. Su halde, irtifak hakları mülkiyet hakkının bahșettiği üç yetkiden ancak ikisini, veya yalinız bunlardan birini bahşeden haklardır. (156) Hak sahibi, ya usus (istimal) hakkına veya usus ile birlikde fructus a (intifa) malik olabilir, ve fakat hiç bir zaman jus abutendi ye sahip bulunamaz.

$2^{\circ}$ ) Irtifat hakları șahsî haklardan, alacak haklarından da farklıdır, zira, bu sonunculara aykırr olarak, irtifak hakları daimidirler, şu manada ki, üzerinde tesis edildikleri sey durdukça devam ederler, ve bu cihetten, her kese karsıı dermeyan olunabilirler.

II - Mülkiyetten gayrı aynî hakların (irtifak) tasnifi.

Irtifak haklan genel olarak șu tasnife tâbi tutulurlar:

- 1. Jus civile irtifak hakları.

2. Pretör hukukunun tanıdığı mülkiyetten gayrı aynî haklar.

Bunlar, Emphytéose, Hypothecạ ve Superficium dur.

III - Hukukî mahiyetleri bakımından irtifak haklarının tasnifi.

Baskasıno ait şeyler üzerinde bir gayrı menkul veya şahıs lehine tesis edilen irtifak hakları iki kategoriye ayrilır:

1 - Ayni irtifak haklanı (Servitutes rerum)

2. Sahsi irtifak hakları (Servitutes personarum)

Birinciler gàyı menkul üzerinde diğer bir gayrı menkul dolayısı ile, ve binnetice, o gayrı menkule malik ve zilyed bütün şahıslar lehine tanınmıs olon irtifak haklaridır.

(155) - D. 10. 2, fr. 47. pr.

(156) - Mülkiyetten cayri avnt haklorin esaslı prensibi, bu haklarin daima baskasina ait șevler üzerinde tesis edilebileceği ile izah olunur: Nemini res sua servit: kendine has sey üzerinde intifak hakkı tesis edilemez. 
İkinciler, bir gayrı menkul üzerinde muayyen bir șahsa tanınmış olan aynî haklardır.

Su halde, her iki kategoriye dahil irtifak hakları arasındaki bariz fark, birincilerinin daimiliqi, ikincilerinin geçiciliğidjir.

Bu farklarına rağmen aynî irtifaklarla şahsî. irtifaklar arasında benzer noktalar mevcuttur:

$\left.1^{\circ}\right)$ Her iki irtifat hakkı, hak sahibine aynî dava bahședer.

$\left.2^{\circ}\right)$ Her iki irtifat hakkı sahibi mücerret maliki irtifat mevzuu üzerinde müspet bir fiil ile tecelli edecek olan mükellefiyete tâbi tutamazlar. Aksi taktirde, irtifak hakkı sihibi ile malik arasında şahsî hak münasebeti mevzubahis olurdu ki, bu, aynî hakların şahsî haklardan ayırdı prensibine aykırı düsser. Irtifak hakkı sahibinin ancak malikini șey üzerinde bu hakkın kullanıtmasını menedici hareketlerde bulunmasıı istemeğe hak vardır.

IV - Jus civile nin kabul etîği mülkiyetten gayrı aynî haklar.

(Servitutes)

1. Aynî irtifak hakları.

Aynî irtifak hakları hâdim gayrı menkul (fond servant) üzerinde hâkim gayrı menkul (fond dominant) dolayısı ile kabul edilmis olan irtifak haklarıdir.

A - Aynî irtifak haklarının müșterek vasıfları.

$\left.1^{\circ}\right)$ Bütün aynî irtifak hakları iki gayrı menkul dolayısı ile mevzu bahistir.

$\left.2^{\circ}\right)$ Bütün aynî irtifak hakları tecezżi kabul etmez, yani hak hâdim erazinin bütünü için mevzu bahistir ve hâkim erazinin bütün sahası lehine mülessestir. Binnetice, gerek hâdim, gerek hâkim erazi malikleri taaddüt etse bile hak devam eder.

- B - Aynî irtifak çeşitleri.

a) Servitutes prediorum rustiquorum.

Bunlar, üzerinde yapı bulunmayan hâkim erazi lehine tesis edilen ve binnetice, ziraatciler için mevzubahis irtifak haklarıdır. Bu irtifak haklarında hâdim ve hâkim arazinin her ikisi üzerinde de yapı bulunmasına lüzum yoktur.

Servitutes prediorum rustiquorum a su dahildir:

$1^{\circ}$ ) Iter: bir eraziden yaya veya atla geçme hakkıdır.

$2^{\circ}$ ) Actus: bir eraziden sürü geçirme hakkıdır. 
$\left.3^{\circ}\right)$ Via: araba ile geçme hakkıdır.

$\left.4^{\circ}\right)$ Aqua ductus: Eski irtifak haklarından olup, hâdim eraziden hâkim eraziye arklar ile su geçirme hakkıdır.

Daha sonraları kabul edilmiş olan aquae haustus, hâdim eraziden su çıkarma hakkıdır. Hâdim erazide koyun veya sürü sulamak ve kum ve saire çıkarma hakkı da Imparatorluk bașlarında kabul edilmiş olan aynî irtifaklardandir. (157)

b) Servitutes prediorum urbanorum. (158)

Uzerinde bina bulunan hâkim erazi lehine tanınmış irtifak. hakkıdır. Bu irtifak haklarından hâdim erazide de yapı mevcuttur.

Servitutes prediorum rustiquorum ile urbanorum arasındaki diğer fark da, ikincisinde hâdim erazi sahibinden müspet bir fiilde bulunmasının da istenebileceğidir.

En eski servitutes prediorum urbanorum cloaca, yani lağam geçirme hakkıdır. Sonraları, komşu erazi ve bina duvarına destek koymak hakkı manzarayı kapamamak hakkı kabul edilmiștir. Destek vurma hakkında hâdim erazi sahibinin müspet fiilde bulunması, meselầ destek vurulan duvarın iyi halde tutulmasını temin etmek gibi, mecburiyeti kabul edilmiștir.

Servitutes urbanorum un kullanılması tarzını taraflar mukavelede tanzim edebilirler. (159)

2. Şahsî irtifak hakları (Servitutes personarúm).

A - Giriş.

Muayyen bir sahıs lehine hayat müddetince veya daha kısa bir zaman için menkul veya gayri menkulleri üzerinde tanınmış olan aynî haklardır.

Aynî irtifak hakları ile bunlàr arasındaki bariz fark iki cihetten hülâsa edilebilir :

$\left.1^{\circ}\right)$ Aynî irtifak hakları müddetle mukayyet değildirler. Bir șahısla bir gayrı menkul arasındaki ilgiden değil, iki gayrı menkul doiayısı ile mevzubahis ilginin ifadesi olduklarından, aynı irtifaklar gayri menkul ile ilgili bütün sahıslar ile alâkalıdırlar.

$\left.2^{\circ}\right)$ Aynî irtifak hakları menkuller. üzerinde mevzubahis değildir.

(157) - Jus utendi veya jus fruendi nin veva bunlardan her ikisinin avnı zamanda ma甘ikten bașka kirine geçmiş olması mülkivetten gayri aynî hakkın doğumunu sağlar.

(158). - R. Monier, Manuel, t. I. p: 434, n: 3, 5 .

(159) - Ed. Cus, Manuel, 1928, p: 330 et s. 
B - Sahsî irtifak çeșitleri.

a) USUS (istimal hakkı)

Baskasına ait bir șeyin cevheri aslîsine, özüne zarar vermeksizin ve semerelerinden, prensip itibariyle, faydalanmaksızın kullanıması hakkıdır.

Bilhassa vasiyei suretiyle intikal eden şeylerde mevzu bahisidi.

Roma hukukçuları intifak hakkı mevzu bahis olmaksızın istimal hakkının faideli olmayacağını çok erken düşünerek, hak sahibinin șahsî ihtiyaçlarının temini nisbetinde intifa hakkına da yer vermekie usus un hak sahsibine yalınız istimal hakkı bahsedeceği kaidesine istisna koymak oldular. Nihayet, vasiyet edilen şey ev ise, usus hakkı sahibine habitatio yu da bahșettiler. (160)

Usus sahibi hakkının șumulü sürekli münakașalara yol açmıșır? (161)

Münakaşa edilemeyecek olan cihet, hak sahibinin mutlaka semerelerden de faydalanabileceğine dair mentinlerde sarahat bulunduğudur. Ancak bu sarahata bakarak, usus ile ususfructus un farksızlığına hükmedilemez. Aradaki fark bârizdir: usus sahibi semerelerin hepsinden faydalanamaz, intifa hakkı sahibi ise seyin bütün semerelerinden prensip itibariyle faydalanır. Diğer cihetten, intifa hakkı tam manası ile usus $u$ da ihtiva eder.

b) Ususfructus (Intifa hakkı). (162)

$\left.1^{\circ}\right)$ Intifa hakkının tarifi ve tarihçesi

Cumhuriyet devri sonlarında (163) görülen intifa hakkı, rakabeye (Proprietas) halel gelmenek, ve binnetice, seyin özünde değişiklik yapılmaksızın, bir şahsın başkasına ait bir şeyi istimal ve bu şeyin semeresinden faydalanma hakkıdır.

Su halde intifa hakkının mülkiyet ile farkı mücerret malikin jus abutendi døn, intifa hakkı sahibinin ise ancak jus utendi ve jus fruendi den faydalana bileceğinden ibarettir. Intifa hakkı, sahibine sey üzerinde malik hâkimiyeti bahsetmez. (164) ancak șeyin semerelerini derleme yetkisi verir. (165)

\footnotetext{
(160) - A. Georgesco, Leges privatae, 1932, p: 49, n: 2.

(161) - D. 7, 8, 2. 1. Hadrianus, bir ormanın usus maksadı ile vasivetini intifa hakkin. dan azâde saymaz.

1162) - Ed. Cuq, Manuel, 1928, p: 340; Riccobono, Studi scialoia, t. 1. 1904, p: 591.

(163) - Ed, Cua. Manuel, 1928, p: 332 et s; Masson, Essai sur la onception de l'usufruit: (Rev. hist, de droit, 1934, p: 1 et s.).

(164) - Dumnot, Rev. hist, de droit, 1943, p: 41 et s.

Mamafih, Cumhurivet devri basilarında da intifaın meveudivetini kabul etmek lozımdır. Cünkü kölenin çocukları üzerinde intifa hakkı mevzu bahis olup olmavaccăı bu devirlerde münakaşa halinde idi: D. $7,1, f r .68$.
}

$(165)-$ D. 45, 3, fr. 26. 
2) Intifa hakkinin movzov.

Intifa hakki seyin özünde değisiklik yapmağa, hak sahibine jus ahün di yetkisini vermeye mütahammil olmadiğından, Klâsik daxi Kădơ oncak ilk istimal ile istihlâk edilemexen menkul ve gayri menkuller üzerinde tesis ounabiliyordu.

Intifa hakkınin ancak ilk kullanma ile yok olabilen şeyler üzermide sis edilememesi vasiyet ettiği mallar arasında bu gibi mallaŕn da davrini yapmıs olan müteveffanın son arzusunun yerine getirilmesine, yani vesinet serbestisi prensibine bir engel teşkil ediyordu. Bu mahzurun önüne gegmak için Klâsik hukukda Quasi ususfructus müessesesinin yer aldığı görülinektedir. Intifa benzeri diye tercüme edilebilecek olan bu tabir hukuki manasi file intifa hakkının değil, belki mülkiyet hakkının ifadesidir. Cünkü itk kullợma ile yok olan seylerden nitifa o seyin özüne (substantia rei) halel getirmeksizin mümkün değildir. Bu suretle, lehine intifaı vasiyet edilen şahıs ilk istimal ile istihlâk edilen seyi tıpkı mücerreł malk gibi kullanmak, yani bu șey üzerinde jus abutendi yetkisini kullanmak imkânına sahip oldu. Ancak, intifa müddeti sonunda istihlâk edilen seyin yerini futan benzer bir seyi veya bedelini (166) vermekle mükellef tutulmus olmakla, seyin cevheri aslísinin iadesi goz ônühde tutularak, müesseseye quasi ususfructus adı verilmekde mahzur görülmemiştir.

Quasi - ususfructus un kabulï ile, alacaklar üzerinde de intifa hakkının tanınıp tanınamayacağı meselesi ehemmiyet aldı. Roma, Ususfructus nominum u da kabul etti; ve alacak üzerindeki intifa hakkınt da quasi ususfructus a benzetti. Binnetice, hak sahibi intifa hakkı sonunda sermayeyi iade ile mükelleftir. (167)

$\left.3^{\circ}\right)$ Intifa hakkı sahibniin hak ve mükellèfiyetleri.

Intifa hakkı sahibinin hakları șu suretle hülâsa edilebilir: Intifa hakkı sahibi, hasilat müstesna, seyin bütün sermerelerinden faydalanur; semere medenî, tabii olsun hüküm aynıdır. Intifa hakkı sahibi zilyed değil, alelôde vazulyed durumunda olduğundan zilyedliğin himayesine ait enterdilerden laydaanamaz.

$(166)$ - D. 7, 3, fr. 1, pr: (Ususfructus in fruendo consistit: intifa semereleri toplamaktan Boreftir.I Intifa hakkı mülkiyetin bir parçası bir kısmı do deb̌ildir: Vaucher IUsufruit ef pars dómini, Lausanne, 1940 aksi fikri güder. Bu oörǔs tarzının doưru olamayacaŏı intif́a hekk sahibinin semerelere deriendikleri andan itibaren malik olacăt: prensibi ile iołdio edilebilir: D. 22, 1, fr. 25, 1; Mamofih, tek bir istisno kabul odilmisti: D. 22, 1, fr. 28, pr.

(167) - Masson, Essoisur la conception de liusufruit, p: 43 ef s. 
Intifa hakkı sahibinin mükellefiyetleri şunlardır: Pretörün müdahalesine kadar, intifa hakkı sahibi ile mücerret malik arasında hukukî bir münasebet mevcut değildi. (168) Netice itibariyle, intifa mevzuunun intifa müddeti sonunda iade edilmemesi, veya başkasına devredilmiş olması ve nihayet intifa hakkı sahibinin mirascıları tarafından mücerret malikin intifa mevzuunu istemesine karşı konulması gibi tehlikeler doğabiliyordu. Bunun önüne geçmek için, pretör, mücerret malik lehine şu iki müessir tedbiri aldı:

a) Intifa hakkı sahibi intifa mevzuunu iyi bir adam, iyi bir aile şefi gibi kullanacaktır.

b) Intifa hakkı sonunda mevzu gerek intifa hakkı sahibi tarafından şahsen, ve gerekse mirasciları tarafindan iade edilecektir.

Intifa hakkı sahibi iki mükellefiyeti Satisdatio ususfructaria, yani, intifa hakkı kefaleti ile ve hakkın kullanılmasına bașlamadan evvel vad etmekle mükellefti. (169)

C - Habitatio (Sükna hakkı).

Habitatio, usus hakkının bir evde oturmak şeklinde tecellisinden ibarettir. Justinianus hukukunda habitatio dan faydalanan şahıs in evi kiraya verebileceği kabul edildi. (170)

D - Operae.

Köle, ve bazı hallerde de, hayvan hizmetinden faydalanmayı sağlayan bir nevi șahsî irtifak hakkıdır. Usus dan farkı, capitis deminito ile ortadan kalkmaması ve bașkasına kiralanabilmesinden ibarettir. Müteveffa bu hakkı bilhassa lakrabası ve daha ziyade karısı lehine vasiyet yolu ile tesis ediyordu.

V - Irtifak haklarının tesis ve sukutu.

1. Irtifak haklarının tesisi.

Cumhuriyet devri sonlarına kadar yalnız aynî irtifak hakları mevzubahis olduğundan ve mülkiyet hakkı ile mahiyetleri itibariyle farksız bulunduklarindan, tesisleri mülkiyetin iktisap yolları ile mümkündü.

(168) -- Nerva, alacak üzerindeki intifa hakkını ancak borçlu lehine yapılmasın vu borçlunun faizlerden kurtarímasł fikrini gütmüs, fakał Proculus bu intifan üçüncü bir sahis lehine de tesis edilebileceği fikrini kabul ettirilmiștir: R. Monier, Manuel, 1945, p: 437

(169) - Girard, Manuel, 1929, p: 392 et s; Giffard, Précis, t. 1. p: 414, No: 705

(170) - Bu vaadi peșinen almamıs olan mücerret malik pretörden himave göremez. Aşağ Imparatorluk hukukunda mücerret malikin Satisdatio usuructoria yl bilâhara temin edebileceŏi de kabul edildi: Girard, Manuel, 1929, p: 395, n: 2. 
Imparatorluk devri başlarından itibaren irtifak haklan res incorporalis mahiyetini almıs olmakla tesis usulleri de değiști. Bu devirden itibaren iki fèsls usulü görülméktedir:

$\left.1^{\circ}\right)$ Translatio servitutis (doğrudan doğruya tesis)

Bu yol ile, müteyeffa vasiyetnamesinde bir șey üzerinde irtifak hakk bahşedebilir. In jure cessio da doğrudan doğruya tesisi temin edebiliyordu: servitüde sahip olmak isteyen, üzerinde servitüt hakkına malik olacağı sey ile majistra önünde muayyen formülü beyan eder, malik de contravinticafío da bulunmamış olmakla servitüd teessüs etmiş olur. Bu usul bilhassa intifa hakkı tesisi için müstamel idi.

Așağı Imparatorluk devrinde servitutes pradiorum lar yine mülkiyet hakkına benzetilmekte olduğundan, tesisleri mancipatio ile ceryan etmekde idi.

Klâsik devirde irtifak hakları res incorporalis kategorisine dahil edildiklerinden usucapio ve traditio ile tesislerine imkân yokłur; çünkü usucapio zilyedliği, traditio teslimi icap ettirir; bu iki şart ise ancak res corporales ler için tahakkuk edebilir. (171)

$\left.2^{\circ}\right)$ Deductio servitutis (172)

Bu usul ile, şeyi devreden malik şey üzerinde kendine irtifak hakkı ayırdığını müșteriye bildirir. Buna bilhassa șu ihtimalleide raslanırdı: erazisini ikiye ayıran ve bir kısmını satan şahıs satılan parça üzerinde sałmadığı erazi lehine ayni bir irtifak hakkı tesis edebiliyordu. Bundan başka, șeyini devreden șahıs şey üzerinde intifa hakkının bekasını derpiş etmek suretiyle hareket edebilirdi.

Justinianus hukukuna kadar irtifak hak!arının tesisinde bazı yeni usuller ihdas olundu: Majistralar ötedenberi kullanilmakda olan ark açma hakkrnın muteber otmass için bir șekil ve merasime lüzum görmüyorlard. (173)

Justinianus hukukunda, mancipatio ve in jure cessio kalktığindan bunlar irtifak haklanın tesisine yaramaz old $v_{;}$bu usuller yertine pactus ve stipulatio tatbikat sahasına konuldu. Bundan başka, servitüdlerin Traditio benzeri ve zamanașımı ile tesisi usulleri de yer aldı. (174)

(171) Just, Inst. II, 5, 5.

- (172) - Servitüdlerin tesisine dair bu görüs tarz!nin larini malûm olmavan lex-Scribonia

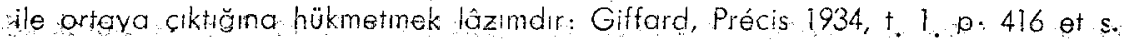

(173) - A. Georgesco, Legies privatae, 1932, p: 5 ; el s.

(174) - Seaevola: D. 39, 3, 26; D. 8, 5, fr. 27; Rabel, Mélangas Girard, 17, p: 407 et s; Bonfante, Corso, II, p: 112 et $s$. 
2. Irtifak haklarının sukutu.

Irtifak hakları sırası ile gözden geçireceğimiz şu usuller ile son bulur:

$\left.1^{\circ}\right)$ Servitutes prediorum rustiquorum lar hâdim veya hâkim erazinin yok olması ile son bulurlar.

Sahsî irtifaklar, bilhassa intifa hakkı, hakkın kullanılmaması ve bu imkânsızlığa yol açan capitis deminitio ile, ve nihayet, mevzuun ortadan kalkması veya başka bir mahiyet alması (175) ile son bulur.

$\left.2^{\circ}\right)$ Vazgeçme de irtifakların sukut sebebleri arasındadır.

Eski hukukda vaz geçme kâfi değildir. Vazgeçme muayyen şekil ve merasime riayet edilerek vaki olmalı idi. Mamafih, pretör, şekle riayeł edilmeden yapıan feragatı kabul ediyordu. Bu takdirde, hak sahibinin jus civile ce hakı baki idi ise de malik feragatten sonra vaki olacak hak iddiasını exceptio ile red edebiliyordu.

$\left.3^{\circ}\right)$ Irtifak hakkının kullanılmaması da sukut sebeplerinden biridir. Ancak, șu ayırda ehemmiyet vermek lâzımdır:

a) Klâsik devirde serviîutes prodiorum rustiquorum, usus ve ususfructus bir ve iki sene içinde kullanılmadığı takdirde sukut ediyordu (176) Bu müddetler justinianus hukukunda 10 ve 20 seneye çıarıldı.

b) Servitutes prediorum urbanorum ların sukutu için yalnız ademi istimal kâfi değildir; aynı zamanda mücerret malikin şey üzerinde bu hakların kulIanılmasını sağlayıcı fiil ve hareketlerde bulunması lâzımdır. Meselâ hakkın taallük ettiği sahaya bina veya hakkın kullanımasını akim bırakacak daha baska fiillerde bulunması gerekirdi. Bu harekâta Usucapio liberatatis denir.

Vi - Irtifak haklarının müeyyidesi.

Irtifak hakkı sahibi iki himaye vasıtası ile himaye ediliyordu.

1. Vindicatio servitutis (veya Vindicatio ususfructus) (177)

Aynî irtifak ve intifa hakkı sahibi bu dava ile hakkın taallük ettiği seyin

(175) - Malik, sey üzerinde irtifak hakkını kullanmakta olan sahsa müsamaha (patiential ederse irtifak hakkının Quasi Traditio ile tesisi mevzubahistir. Klâsik devirden itibaren de, müddeti muayyen olmayan bir zaman asımının irtifak haklarının tesisinde rol aldığ iddia edilmektedir: Ed. Cua, Manuel, 1928, p: $345, n: 2$. Justinianus hukukunda irtifak haklarının tesisi için lâzımgelen zaman așımı sürelerinin 10 ve 20 sene olarak kabul edildiği ileri sürülmektedir: Giffar, Précis, t. 1, p: 419, n: 2 .

(176) - Pierre - Eugène cavin, L'extinction de l'usufruit rei mutatio, Thèse, Lausanne, 1933

(177) - Paulus, Sent. 1. 17; III, 6. 30. 
zilyedliğine sahip olur ve bu sey üzerinde hakkı kullanma imkânını elde eder.

Mamafih, erazi sahibinin de Actio negotaria ile erazisinin aynî irtifak hakları ile veya intfia ile mukayyet bulunmadığını iddia ve ispata hakkı mahfuzdur. (178)

2. Interdictum lar. (179)

Servitutes prediorum rustiquorum lardan geçit, ark açma ve su çkarma hakları interdictum lar ile temin edilmiști.

Servitutes prediorum ubranorum lar için ancak bir tip interdictum tatbikatta idi: Interdictum cloacis (180). Bu enterdi ile hak sahibi lağımların temizlettirilmesi ve tamirini temin eder.

Hak sahibinin gayrin erazisinde veya binassnda müspet bir fiilde bulunmaya salâhiyetli kılan, meselâ, intifa, usus ve habitatio gibi, servitutes urbanorum sahipleri zilyedliğin himayesine aif enterdilerden faydalanırlar. Bu imkânın quasi possessio nazariyesine menşe teșkil ettiği umumiyetle kabul edilmektedir. (181)

VII - Mülkiyetten gayri pretör aynî hakları.

Hâkim tasnife göre, irtifak haklarından daha sonra kabul ve tanzim edilmiş olan mülkiyetten gayri pretör aynî hakları, sırası ile tetkik edeceğimiz su dört tipi gösterir.

\section{Superficium (üst hakkı) (182)}

Başkasına ait bir erazi üzerinde yapılmış bir binadan muayyen bir kíra vermek şartı ile faydalanma hakkıdır.

Ilk devirlerde bu hak Devlete ait erazi üzerinde mevzubahis iken, sonraları, özel kişilere ait erazi üzerinde kabul edildi: muayyen bir eraziyi kiralamıs olan sahıs o erazi üzerinde yapacağı inșaattan da faydalanma hakkına sahip idi. Evvelâ șahsî bịr hak olan superficium, sonraları, pretörün mü-

(178) - Bu dâva, Justinianus devrinde, actio confessoria adını tassır: Bonfante Corso, IIl, 1933, p: 121; G. Sergé, Mélanges Girard, 11, 1912, p: 511 et $s$.

Hâkim, dâva edileni ya sevin tesiimine veya irtifak hakkının kullanılmamasını taminen yapilacak olan hareketlerde bulunmamaya davet eder: Girard, Manuel, 1927. „0: $1086, \mathrm{n}: 2$. Bu hükme riayetsizlik para cezasını muciptir:, 8, 5, fr. 7 .

(179) - Lenel, Ediclum, 3 éd, p: 190 et s.

(1180) - Bonfante, Corso, Ill, p: 366 et s.

$\$ 1811$ - Girard, Manuel, 1929, p: 408 et s.

(182) - R. Monier, Manuel, 1945, p: 344, n: 3. 
dahalesi ile, ayni bir hak mahiyetini ald, ve actio in rem ile müeyyidelendi. (183)

Așağı Imparatorluk devri bu hakkı teferruatı ile tanzim etmiş, ve üzerinde superficium mevzubahis inşaatın irtifak hakları ile de mukayyet olabileceğini kabul eylemiştir. (184)

Ust hakkı yaşayanlar arasındaki tasarruflar ile intikal edebileceği gibi, mirascilara da geçer.

2. Jus in agro vectigali (veya, Jus perpefuum)

Devlete ait olup sahıslara gayri muayyen bir süıc için ve Vectigal (4) denilen bir gelir vermek suretiyle bahşedilen uzun vadeli erazi icarından ibarettir.

Hak mirascilara intikal eder (185). Hak sahibi eraziye tecavüzün men'ini def'e yetkilidir. Nihayet, hukukçular bu hakka aynî bir hak mahiyeti tanidilar. (186)

Jus in agro vectigali beșinci asır sonlarında Emphytéose la karıștı ve rolünü ona terk etti. (187)

3. Emphytéose. (188)

Bidayetlerde Imparatorlara ait ekilmemiş erazinin ișletilmesini temin için yapılan bir icar mukavelesidir. Illk defa șimalî Afrikada meriyette iken, sonraları Avrupada, ve bilhassa, Italyada tanınmıs ve Kilise ercizisi ile ferdî erazilere de ratbik edilmeye bașlanmıştir.

Müessesenin adı, kiracının eraziyi ağaçlandırması ve' ıslâh etmesi manasına gelen yunanca bir kelimeden gelir. (189)

Mutad olarak Imparatorluk erazisine tatbik edilen bu mukaveleler evvelâ kiracıya muayyen ve senelik bir irad (canone) vermesi ve eraziyi zira-

(183) -- Haịie, Etude sur les locations à long terme et perpétuelles, Thèse, Paris, 1926. p: 132 et et $s ; \mathrm{Ed}$. Cuq, Manuel, 1928, p: 325 et $\mathrm{s}$.

$1184-$ D. 43, 18, fr. 1, 9.

(185) - Gaius, Inst. III, 145.

(186) - D. 50, 16 fr. 210

(187) Beseler (Studia etdocumenta, 1937, p: 360 et s) gibi bazı müelififer aksi fikirde sseler de metinler sarihtir: D. 30, fr. 71, 5-6.

(188) - R. Monier, Manuel, 1945, t. 1. p: 446, n: 2.

(189) - W. Kamps, L'Emphytéose en doit grec et sa réception en droit romain, Recuei! de la Société J. Bodin, III, 1938, p: 67. 
ate elverişli hale getirmesi şarłı ile şeyin mülkiyetini ucuz bir bedel mukabilinde devre yariyordu.

Kiracıya mülkiyet intikal etmeksizin ve ancak onu eraziyi işletmek şartı ile muayyen bir müddet sonunda ehemmiyetsiz bir miktar hâsılat yatırmaya mecbur tutan Emphytéose tipi de fazlasi ile tatbik olunmakta idi.

Emphytéose da mirascilara intikal eder. Hak sahibi mukavelede muayyen Salvo canone yi ödedikçe eraziden çıarılamaz:

Justinianus devri Enphytéose mukavelesinden doğan hakkı aynî bir hak olarak mütalâa eder. (190)

4. İpotek.

Alacaklının borçlunun menkul veya gayri menkulünü takyit etmesi hasebiyle ipotek de mükiyetten gayri aynî haklar arasında mütalâa edilmelidir.

(190) - Binaenaleyh, hak sahibi mülkiyeti garantileven davalardan faydalanır. Ancak üc seneden fazla bir süre içind evergi veya gelir ödenmediği takdirde, mülkiyet asıl sahibine rücu eder. Bundan baska, kiracı mücerret malikin rızasını almadikça arazivi satamaz. Bu hususta bir tefrik yapmak zarurîdir: 11 Eğer mukPavele kiracrva araziyi de devreden bir emphytéose tipi ise, bu rizaya mahal voktu. 2) Aksi takdirde hal caresi prensibi takip eder; mamafih, bu sonuncu halde de, malik șif'a hakkı kullanacaŏın be. yan etmedikse satısa múhalefet edemez.

Su haide, emphytéose un tam bir mülkiyet hakkı bahsedeceği fkirinde bulunmak doğru değildir, çünkü arazi sahibinin kiracı tarafından satılması halinde semenin bir kismına hakkı vardir: Hoiiie, op. cit, p: 136, - 155 et s. 